\title{
MEASURING EFFECTIVE TAX RATES ON Human CAPITAL: METHODOLOGY AND AN APPLICATION TO CANADA
}

\author{
KIRK A. COLLINS \\ JAMES B. DAVIES
}

CESIFO WORKING PAPER NO. 965

CATEGORY 1: PUBLIC FinANCE

JUNE 2003

Presented at CESifo Conference on MEAsuring the TAX BuRden On LABOUR AND CAPITAL, Venice, July 2002

An electronic version of the paper may be downloaded

- from the SSRN website:

www.SSRN.com

- from the CESifo website: www.CESifo.de 


\title{
Measuring EFFECTIVE TAX RATES ON Human CAPITAL: METHODOLOGY AND AN APPLICATION TO CANADA
}

\begin{abstract}
This paper examines the impacts of a wide range of tax provisions on the incentive to invest in human capital, and shows how these effects can be quantified using effective tax rates, or ETRs. For individuals with median earnings, ETRS on the human capital formed in firstdegree university study are sizeable, although not as large as those estimated by previous authors for physical capital in Canada. When the expenditure side and its direct subsidies are also taken into account, the net effective tax rate on human capital becomes negative. The taxation of human capital is far from uniform. ETRs vary by income level, gender, part-time vs. full-time study, whether students have loans, number of dependants, and use of RESPs. The most significant differences are those related to income level. Workers at higher percentile levels of the earnings distribution throughout life may face ETRs three times as high as those for low-income workers - a result of our progressive income tax system.
\end{abstract}

JEL Code: H2, H3.

\author{
James Davies \\ Department of Economics \\ University of Western Ontario \\ London, Ontario N6A 5C2 \\ Canada \\ jdavies@uwo.ca
}

\author{
Kirk A. Collins \\ Department of Economics \\ University of Ottawa \\ Ottawa, Ontario K1A 0G9 \\ Canada
}

We gratefully acknowledge the support of the Institute for Research on Public Policy. We would also like to thank John Burbidge for helpful comments and for assistance with the earnings data. Responsibility for any errors or omissions is our own. 


\section{Introduction}

Over the last two decades there has been a considerable amount of research on effective tax rates on physical capital. It has been found that these are generally high, and that they vary across types of firms, industries, and types of capital. (See Boadway et al., 1984; King and Fullerton, 1984; and McKenzie et al., 1998.) While the size of the impact on investment and its composition is an important question that cannot be addressed simply by estimating tax wedges, these findings have helped to create concern about such impacts. This has added impetus to the movement to reduce capital taxation and to make it more uniform.

While there has also been considerable interest in recent years in the tax treatment of education and training ${ }^{1}$, we do not have estimates of the effective tax rates on human capital. This is a problem since some features of the tax system, e.g. progressivity, tend to discourage human capital formation, while others, e.g. deductions or credits to support education, have the opposite effect. We do not know the net impact, and therefore do not know whether the tax system encourages or discourages human capital; how it treats human capital compared with physical capital; or how effective tax rates on human capital vary across the population.

This paper provides a conceptual framework for measuring effective tax rates (ETRs) on human capital, analyzing how the progressivity of personal income taxes interacts with other PIT features, other taxes, and student loan plans. It then provides estimates for the ETRs on human capital formed in first degree university studies in Canada. $^{2}$ We find that these are sizeable although not as large as effective tax rates on physical capital, and that they vary considerably across individuals. ETRs on human capital in Canada are, on average, greater for males than for females, and increase as we go up the income scale. ETRs are lower for individuals who take out student loans, and for those who take advantage of Registered Education Savings Plans (RESP's). There are also differences in ETRs created by a number of other tax features. The conclusion is thus that Canada has far from uniform tax treatment of human capital.

In assessing fiscal incentives or disincentives for human capital investment it is essential to take into account the encouragement that governments provide for such investment, on their expenditure side. For a more complete treatment one therefore needs to consider the effective subsidy rate, ESR, as well as the ETR. ${ }^{3}$ The "bottom line" is given by the net effective tax rate, ETR - ESR. As we show, this net tax rate is on average negative.

Care must be taken in interpreting the results of our study. This is especially so if one wishes to draw normative implications. First there are some standard considerations from the economics of education. A negative net tax on human capital can, in principle, be justified by positive externalities of education or by capital market imperfections that make it hard for students to borrow. However, while earlier literature claimed to find evidence of large externalities, recent work tends to dispute this (see e.g. Heckman and Klenow, 1997; Acemoglu and Angrist, 2000; and the survey by Davies, 2002). Doubt 
has also recently been cast on the importance of borrowing problems (see e.g. Shea, 2000; Cameron and Taber, 2000). Merit good arguments are sometimes also used. On the other side, to the extent that education represents private consumption rather than an investment the strength of subsidy arguments declines. Going further, if education pays off for individuals due to screening for ability, or because of the status it confers, it is wasteful from a social viewpoint, and should be discouraged. The bottom line that should be taken from economics of education considerations is thus unclear.

Turning to the public finance literature, there are several strands. A variety of studies have endogenized human capital in dynamic models, either in a neoclassical framework (see e.g. Davies and Whalley, 1991; Trostel, 1993; Perroni, 1995; Jones et al., 1997) or with endogenous growth (see e.g. Pecorino, 1993; Jones et al., 1993; Davies et al., 2002). It is well-known that the optimal tax rate on physical capital goes to zero in the long-run in perfect foresight infinite horizon dynamic models (Judd, 1985; Chamley, 1986). A similar result extends to human capital when it is endogenized (Jones et al., 1997). However, results of recent studies suggest that this need not imply zero labor income taxes. Bovenberg and Jacobs (2002) and Davies et al. (2002) both show that education subsidies can be used to counter the disincentive effect of labor income taxes on human capital formation. An important element in our study is to see how complete this offset is in practice. Another interesting recent insight is provided by Nielsen and Sorensen (1997) who show that if the imposition of capital income taxes cannot be avoided there may be excess investment in human capital, which can be combatted by levying progressive labor income taxes. In other words, if the effective tax rate on physical capital is unavoidably positive, then the optimal tax rate on human capital may be positive as well.

The remainder of the paper is organized as follows. Section II provides a description of the conceptual framework adopted. In Section III we examine the treatment of human capital under the Canadian tax system. Finally, Section IV presents our numerical results, and Section V concludes.

\section{Conceptual Framework}

A common approach in evaluating the impact of factor taxes is to juxtapose effective tax rates on physical capital with tax rates on labor. In this context, if labor income were taxed at a proportional rate of $30 \%$, for example, and the EMTR for physical capital were, say, $20 \%$, it would appear that the tax system discriminates in favor of physical capital. However, as is now well-known (see e.g. Davies and Whalley (1991), if the only private cost of education is forgone earnings, a proportional labor income tax is neutral with respect to human capital investment. (It implicitly subsidizes the costs at the same rate it taxes the benefits of education.) In the example given, the tax system would in fact heavily discriminate in favor of human capital. Thus, it is as important to include impacts on investment costs on the labor side as it is on the physical capital side. There is an increasing trend to do this (see e.g. Mintz, 2001, for Canada). Our purpose here is to highlight the impact of taking these investment aspects into account. $^{4}$ 
How can one tell whether a tax system provides a net incentive or disincentive for investment? This problem has been analyzed by previous authors for the case of physical capital. Structures, equipment, and inventories are taxed in different ways, and there are also differences across industries and according to how investment is financed. In order to summarize these effects and see how they net out, it has proven fruitful to calculate hypothetical effective marginal tax rates (EMTRs) by type of capital, industry, and method of finance. (See, e.g., Boadway et al., 1984; King and Fullerton, 1984, and McKenzie et al. 1998.)

EMTR's on physical capital are high and non-uniform. Looking only at nonpersonal taxes, McKenzie et al. (1998), for example, find that EMTRs in Canada in 1997 averaged $29.0 \%$ on inventories, $19.0 \%$ on machinery, $18.9 \%$ on structures, and $15.6 \%$ on land. The overall average EMTR was $21.8 \%$. Rates within industries ranged from $8.5 \%$ in agriculture, fishing and trapping, to $29.5 \%$ for public utilities. Largely due to their lower rate of corporate income tax, small firms on average faced an EMTR of only $13.3 \%$ while large firms paid $27.0 \%$.

Personal taxation of capital income is also significant and highly non-uniform. Poddar and English (1999) estimate that about $75 \%$ of investment income is tax-free at the personal level in Canada - - due to various tax shelters (e.g. retirement savings plans) and other factors such as the non-taxation of imputed rent on owner-occupied housing. On the other hand, tax rates on the interest, dividends, and capital gains that are not sheltered can be quite high. There are no estimates of personal-level EMTRs on capital income for Canada. However, most investors would have paid tax on taxable elements of investment income at top marginal rates, which averaged about $46 \%$ in Canada in 1997 , including provincial taxes. Applying the Poddar and English result, the average personal EMTR on investment income may then have been about 10\%. Added to the McKenzie et al. figure, this suggests an average total (personal plus non-personal) EMTR on physical capital of at least $30 \%$.

While the problem of measuring effective tax rates on human capital is formally the same as that for physical capital, there are measurement issues that make a different approach necessary in practice. ${ }^{5}$ In the case of physical capital one can make plausible assumptions about the rate of return to a hypothetical marginal investment based on observed asset returns in capital markets. For human capital rates of return are not directly observable. For physical capital the fact that real-world investments are typically lumpy does not affect the results. Corporate taxes are levied at a flat rate, so the estimated effective tax rate does not depend on the size of the investment. For human capital the most important tax is the personal income tax, whose graduated rate structure makes the effective tax rate depend on the scale of the investment.

For human capital rates of return can be estimated using microdata on education and earnings over the lifetime. Tax treatment depends on individual circumstances and requires a comparison of the taxes that would be paid in the counterfactual, i.e. without additional education, vs. those paid if extra schooling is obtained. The most meaningful 
calculation compares the before- and after-tax rates of return to participation in a complete education program, whether it be e.g. community college, undergraduate university study, M.A. or Ph.D. work. ${ }^{6}$ These tax rates are similar to the EMTR's on physical capital in that they measure the effective tax rate on the last meaningful unit of education, but since these units are not small we speak in terms of "effective tax rates" (ETR's) on human capital rather than EMTR's below.

The ETR for human capital is defined as the gap between gross- and net-of-tax rates of return to a whole program of study, $r_{g}$ and $r_{n}$, respectively:

$$
E T R=\frac{r_{g}-r_{n}}{r_{g}}=1-\frac{r_{n}}{r_{g}}
$$

This definition, which is built on the use of internal rates of return, follows the methodology applied in computing ETRs on personal financial assets by Davies and Glenday (1990). ${ }^{7}$

Suppose that an individual aged $t$ is planning to engage in a program of education that will take $m$ years of study. We will assume that after this program is completed the individual will stay in the labor force until age $T$. Students may continue to earn while going to school. Their wage rates can vary over time, perhaps increasing while they are still in school, and likely rising in real terms over much of the lifetime after graduation. Actual earnings before-tax are given by $E_{t}$, which is the product of the wage rate and hours worked. Earnings before-tax in the absence of the educational program would have been $E_{t}^{*}$, where we assume that $E_{t}^{*}<E_{t}$ in the $T-m$ years after graduation. Forgone earnings costs of education, $F E_{t}$, are thus $E_{t}^{*}-E_{t}$ in the first $m$ years. In addition to these costs, there are private direct costs of education, $C_{t}$. After-tax variables will be denoted $E_{t}^{a}, E_{t}^{a *}, F E_{t}^{a}$, and $C_{t}^{a}$. Initially we will assume that human capital investments are self-financed, that is that student loans are absent.

Rates of return on the investment described are calculated as internal rates of return. For example, we can compute the gross private rate of return, $r_{g}$, from:

$$
\sum_{t=1}^{T} \frac{E_{t}-C_{t}}{\left(1+r_{g}\right)^{t-1}}=\sum_{t=1}^{T} \frac{E_{t}^{*}}{\left(1+r_{g}\right)^{t-1}} .
$$

By replacing $E_{t}, E_{t}^{*}$, and $C_{t}$ with the after-tax variables $E_{t}^{a}, E_{t}^{a^{*}}$, and $C_{t}^{a}$, we could compute the net after-tax rate of return, $r_{n}$, using this same equation. Note that in the case of a flat tax with tuition and other direct costs of education deductible $r_{n}=r_{g}$, and $E T R=0$. This is because with such a tax levied at the rate, say, $\tau$, we have $E_{t}^{a}=(1-\tau) E_{t}, E_{t}^{a *}=(1-\tau) E_{t}^{*}$, and $C_{t}^{a}=(1-\tau) C_{t}$. That is, the three variables have the same relative values after- as before-tax. We shall refer to this type of tax system as neutral with respect to human capital. ${ }^{8}$ It imposes a zero ETR because the forgone 
earnings and direct costs of education are implicitly subsidized at the same rate, $\tau$, at which the gains from education are taxed.

Note that "neutrality" is used here in a special, and very limited, sense. It is simply a benchmark. There is no implication that a zero ETR on human capital is the optimal rate. Externalities of human capital, or capital market imperfections that make it difficult for students to finance their studies, could call for a negative ETR. Absent such factors, a non-zero ETR could be needed in the second-best solution if there were a positive EMTR on physical capital. In that case, while a low ETR would avoid depressing investment it would also tilt the playing field away from physical capital investment, causing a distortion in the composition of investment. Clearly, optimal design of the tax treatment of human capital is contingent on any constraints (political or otherwise) on the tax treatment of physical capital.

By replacing private costs with public costs, $C_{t}^{p}$, we can use (2) to compute the public rate of return, $r_{p}$. Given $r_{p}$ we can define the effective subsidy rate $(E S R)$ on human capital:

$$
E S R=\frac{r_{g}-r_{p}}{r_{g}} .
$$

Whether the tax and expenditure systems combined have an incentive or disincentive effect on human capital investment can be investigated by computing the net effective tax rate on human capital, ETR - ESR. We proceed here by first analyzing the behaviour of $E T R s$, and returning to ESRs at the end of the section.

The behaviour of ETRs can best be illuminated if we assume, for the sake of illustration, that the length of the schooling program, $m$, is just one year. Rearrange (2) so all the $t=1$ terms are on one side and the remaining terms on the other:

$$
E_{1}^{*}-E_{1}+C_{1}=\sum_{t=2}^{T} \frac{E_{t}-E_{t}^{*}}{\left(1+r_{g}\right)^{t-1}}
$$

The left-hand side of (4) represents the private costs of the education program, made up of foregone earnings, $E_{1}^{*}-E_{1}$, and direct costs, $\mathrm{C}_{1}$. The right-hand side is the present value of future earning increments due to education, $E_{t}-E_{t}^{*}$.

Again for the sake of illustration, suppose that the yearly benefits of additional education, $E_{t}-E_{t}^{*}-C_{t}$, are constant. Then because $T$ is typically large we have:

$$
E_{s}^{*}-E_{s}+C \approx \frac{E_{w}-E_{w}^{*}}{r_{g}}
$$


where we use subscripts $s$ and $w$ to denote the schooling and working periods. We now have a simple expression for the before-tax rate of return $r_{g}$ and a parallel expression for the after-tax rate of return, $r_{n}$ :

(i) $\quad r_{g} \approx \frac{E_{w}-E_{w}^{*}}{E_{s}^{*}-E_{s}+C}=\frac{E I}{F E+C}$

(ii) $\quad r_{n} \approx \frac{E_{w}^{a}-E_{w}^{a^{*}}}{E_{s}^{a^{*}}-E_{s}^{a}+C^{a}}=\frac{\left(1-\tau_{w}\right) E I}{\left(1-\tau_{s}\right) F E+C^{a}}$

where $F E$ is forgone earnings and $E I$ is the "earnings increment" achieved due to the extra education. Both $F E$ and $E I$ are before-tax. The tax rates $\tau_{s}$ and $\tau_{w}$ represent the fraction of $F E$ that would have been paid in tax, and the fraction of $E I$ that is paid, respectively.

If we ignore direct costs for the time being and let $T \rightarrow \infty$ for simplicity we have:

$$
\left.r_{g}\right|_{C=0}=\frac{E I}{F E}
$$

$$
\left.r_{n}\right|_{C=0}=\frac{\left(1-\tau_{w}\right) E I}{\left(1-\tau_{s}\right) F E}
$$

Applying (1) the effective tax rate on human capital in this case is:

$$
\left.\operatorname{ETR}\right|_{C=0}=\frac{r_{g}-r_{n}}{r_{g}}=\frac{\tau_{w}-\tau_{s}}{1-\tau_{s}}
$$

This simple expression has some interesting implications. It indicates that, in the absence of direct costs, the effective tax rate on human capital is directly related to the gap between $\tau_{s}$ and $\tau_{w}$. The most obvious possibility is that the graduated rates under personal income tax will make $\tau_{s}<\tau_{w}$, resulting in a positive ETR. The gap between $\tau_{s}$ and $\tau_{w}$ will tend to be largest for those education programs that have the biggest impact on earnings. This is one reason that first-degree university education is of particular interest. Not only is it a very important element in our education system, but it is well-known to increase earnings substantially. In contrast, incomplete university education, or graduate education, have smaller effects on earnings, which will result in a smaller gap between $\tau_{s}$ and $\tau_{w}$. Equation (7) gives reason to expect smaller ETR's in these cases.

Of course other taxes also affect the ETR. Since social security and unemployment insurance contributions are capped at maximum insurable earnings, their 
schedules are regressive. To the extent that contributions represent pure taxes (i.e. not offset by expected benefits), these schemes work towards $\tau_{s}>\tau_{w}$ for workers whose EI's fall entirely or partly above maximum insurable earnings. It should also be borne in mind that sales taxes reduce real earnings. In the absence of any other taxes, proportional sales taxes on a comprehensive base would give $\tau_{s}=\tau_{w}$, that is neutrality. However, some necessities are widely exempt from sales tax in North America and elsewhere (food, children's clothing etc.) or taxed at a lower rate, which reinforces the tendency for $\tau_{s}<$ $\tau_{w}$, and a positive ETR.

Expressions (6) and (7) also make possible a number of other insights. We note that:

Result 1: If $\tau_{s}<\tau_{w}$, equal absolute or equal proportional increases in $\tau_{s}$ and $\tau_{w}$ will reduce $\left.r_{n}\right|_{C=0}$ and increase $\left.E T R\right|_{C=0}$.

This result hinges on the fact that with $\tau_{s}<\tau_{w}$, we have $\left(1-\tau_{s}\right)>\left(1-\tau_{w}\right)$. Equal absolute or proportional changes in $\tau_{s}$ and $\tau_{w}$ have a greater proportional impact on $\left(1-\tau_{w}\right)$ than on $\left(1-\tau_{s}\right)$. The effect is of course stronger in the case of equal proportional changes in the tax rates.

Result 1 is of interest when more than one tax is levied. It points out e.g. that even if a tax would be neutral on its own, when added to an existing system that imposes a positive tax rate on human capital it will increase the size of the tax wedge. If one perhaps thought of the federsl personal income tax as the basic element in the system, then adding even uniform sales taxes or flat-rate provincial income taxes raise the ETR.

Moving to the more general case, we need to take into account tuition and other direct costs; the student loan amount, $L$; student loan repayments, $i L$, where $i$ is the interest rate; the rate of tax relief on student loan payments, $d$; and credits for tuition and other expenses, $A .^{9}$ Making the appropriate adjustments to the costs and returns we have:

$$
E T R=1-\frac{r_{n}}{r_{g}}=1-\left[\frac{\left(1-\tau_{w}\right) E I-i(1-d) L}{\left(1-\tau_{s}\right) F E+(C-L-A)}\right]\left[\frac{F E+C-L}{E I-i L}\right]
$$

From (8) we have immediately:

Result 2: Increases in tuition credits, $A$, or in interest deductibility, $d$, unambiguously reduce the ETR.

Note also from (8) that the ETR is affected by several non-tax policy variables, e.g. tuition fees, student loan amounts, and interest rates on student loans. These interaction effects are perhaps unexpected, and therefore particularly interesting. It should be emphasized that they are independent of the impact of these non-tax variables on the effective subsidy rate on education. We summarize these effects in Results 3 and 4. (Proofs are available in an appendix that may be obtained from the authors.) 
Result 3: A rise in tuition and other direct costs, $C$, raises the ETR.

The intuition for this result is that if $C$ rises, with education credits $A$ constant, the implicit rate of subsidy to direct costs of education in the tax system has fallen. The result is of topical interest in Canada and other countries, like the U.S., where tuition fees have been rising rapidly in recent years. In the absence of offsetting action in the tax system, such increases raise the tax distortion affecting human capital. Rising tuition fees may also reflect a reduced rate of public subsidy to colleges and universities, meaning that the ESR has been falling. Thus the net effective tax rate on human capital, ETR ESR tends to rise a fortiori.

In the next section we set out the many steps that have been taken at the federal level in Canada in recent years to ease the tax treatment of human capital. These initiatives will have acted to offset the rise in ETRs caused by increasing tuition fees and other direct costs.

The following result reflects the effect of student loans:

Result 4: If $d \geq \tau_{w}$ the ETR is strictly decreasing in $L$. If $d<\tau_{w}$ the sign of the effect of $L$ on the ETR is ambiguous.

Thus, a sufficient condition for an increase in student loans to reduce the effective tax rate on human capital is that the fraction of student loan interest that is creditable should exceed the tax rate on the earnings increment due to education. In the calculations reported in Section IV below we find that this is the direction of the effect in most cases we consider.

We should say a few words about the effective subsidy rate, ESR, which was defined in (3). Note that the ESR depends only on $r_{g}$ and $r_{p}$. It is thus independent of any aspects of the tax system (in a partial equilibrium framework). It can, however, be affected by the presence of student loans, since as we saw in (8) these affect $r_{g}$. (Student loans have no effect on $r_{p}$, however.) ${ }^{10}$

Let $\sigma=1-C / C^{p}$ be the rate of subsidy on the direct costs of education. Then, in the absence of student loans, the wedge between $r_{g}$ and $r_{p}$, and therefore the ESR, will be greater the larger $\sigma$ or $C^{p}$, as we can see from:

$$
\left.E S R\right|_{L=0}=\sigma\left[C^{p} /\left(F E+C^{p}\right)\right]
$$

which is derived from (3) and 5(i), noting that 5(i) yields $r_{p}$ if $C$ is replaced by $C^{p}$. Introducing student loans will tend to raise $r_{g}$ if the student loan interest rate is less than $r_{g}$ (which is plausible). This is likely to raise $r_{g}$ relative to $r_{p}$ and increase the ESR. 


\section{Treatment of Human Capital under Canadian Tax and Student Loan Systems}

The calculations in the next section incorporate the effects of both the personal income tax system (federal and provincial) and payroll taxes, as they applied after the federal budget of 1998, which made a number of important changes in the tax treatment

of education. ${ }^{11}$ Here we describe the relevant features of the PIT and payroll tax systems, noting the reforms introduced in 1998 (as well as changes leading up to those reforms) and developments since. We also describe the student loan system as it existed in 1998, and note more recent changes.

\section{Personal Income Tax}

A useful benchmark for describing how PIT impinges on human capital is a flat tax system under which direct costs of education or training are fully deductible. Interest on student loans would not be deductible. Under such a neutral system, ETR $=0$. Canadian PIT departs from neutrality by levying graduated marginal tax rates, in its treatment of direct costs, and (since 1998) by allowing a credit for interest on student loans.

Both federal and provincial PIT are levied on individuals, unlike the U.S. where most married couples are taxed jointly. In 1998, basic federal marginal rates of 17\%, 26 $\%$ and $29 \%$ were levied on taxable income in the ranges 0 - $\$ 29,590, \$ 29,591-\$ 59,180$, and $\$ 59,181+$. (These rates and brackets were in force from 1993 to 1999.) Adding in surtaxes and provincial income tax, the full marginal rates in the three brackets came to about 26, 40, and 46\% in 1998 (Canadian Tax Foundation, 1999, Table 3.5). Important deductions made in arriving at taxable income included those for Registered Retirement Savings Plan (RRSP) and Registered Pension Plan (RPP) contributions and child care expenses. Rather than providing personal allowances or exemptions as in most other countries, a system of personal credits was applied. These gave all taxpayers the same relief as if they had received personal deductions but were in the $17 \%$ marginal tax bracket. On that basis, the credits given were equivalent to deductions of $\$ 6,456$ for the taxpayer and \$5,380 for a dependent spouse or child over 18 .

Refundable tax credits for children under 18 were provided via the Canada Child Tax Benefit (CCTB) and the National Child Benefit Supplement (NCBS). The latter were clawed back on family net incomes above $\$ 25,921$ and $\$ 20,921$ respectively. These programs have little impact on costs of education, since relatively few students have children, but they increase marginal tax rates for many graduates, and will therefore drive up the ETR on human capital somewhat. ${ }^{12}$

The tax relief on tuition and other direct expenses provided by the PIT comes in the form of various credits, not as a deduction. In 1998 a credit was given for $17 \%$ of tuition and additional mandatory fees paid to approved post-secondary institutions. A further credit equal to $17 \%$ of an "education amount" was provided. The education amount was $\$ 80$ per month prior to 1996 , but was raised in steps to $\$ 200$ per month by 1998. Since most students have low incomes, these credits would in many cases not be 
very valuable if they were only available to reduce the student's own tax liability. Their value is enhanced by the fact that any unused portion can be transferred to a spouse, parent or grandparent. ${ }^{13}$ Also, in 1997 a carryforward provision for unused education credits was introduced that would allow students to obtain tax relief themselves in later years. These measures ensure that the effective implicit federal subsidy on direct costs of education via PIT is close to being uniform at a $17 \%$ rate. Adding in provincial tax, the average rate of relief is about $26 \%$.

Note that the "education amount" credits are not related to actual expenditures, but are simply paid as a lump sum. They are thus similar to a system of student grants. This form of assistance would not have a tax-side rationale under a flat tax, but with progressivity might be advocated as a rough offset to the effect of graduated marginal tax rates on human capital ETRs.

The PIT system also provides assistance for education and training via registered savings plans. First, Canadians are able to withdraw funds from their RRSP's without penalty two years after contributions are made. This means that, assuming contribution limits are not binding, parents could save for their children's post-secondary education via their RRSP's. While this avenue is no doubt sometimes chosen, it is not as attractive as it might be since RRSP contribution limits have been held at relatively low levels. ${ }^{14}$ Also, withdrawals are taxed. Parents will typically be in their peak earning years when their kids go to college, and will therefore face high tax rates on withdrawals. This will also make the RRSP saving route less attractive.

Parents are encouraged to save for their kids' education via Registered Education Saving Plans (RESP's). In contrast to an RRSP, contributions to an RESP are not tax deductible. However, income earned within the plan is tax free, and if the proceeds are spent on the child's education withdrawals of accrued income enter the child's income for tax purposes. Given that post-secondary students are generally in low tax brackets, the result is that the net of tax rate of return on RESP saving generally exceeds that on nonsheltered saving. ${ }^{15}$ While RESP's provide a higher rate of return than on non-sheltered saving, in the pre-1998 regime they were not sufficiently attractive to induce much use. This may have been due to the opportunities for fully sheltered saving (e.g. via RRSPs) or because a higher rate of return could be achieved by paying down mortgages and consumer debt. ${ }^{16}$

The 1996, 1997 and (especially) 1998 federal budgets introduced a number of changes intended to reduce burdens on post-secondary students and to stimulate education and training in Canada. The following were the principal changes:

1. The 1996 and 1997 budgets announced that the education amount would be raised from its original \$80 per month to \$150 per month in 1997 and \$200 per month in 1998 .

2. The education amount was extended to part-time post-secondary students in the 1998 budget, at $\$ 60$ per month. Part-time students also became eligible to claim child care expense deduction (CCED) for the first time, up to $\$ 2,200$ per year. 
3. Canada Study Grants (CSG's) of up to $\$ 3,000$ per year were created in the 1998 budget for both full- and part-time students in financial need who had children or other dependants.

4. Interest on student loans became eligible for a tax credit at the $17 \%$ rate in the 1998 budget.

5. Tax-free withdrawals of up to $\$ 10,000$ per year $(\$ 20,000$ in total) from RRSPs were introduced in the 1998 budget to finance full-time training or education (or parttime for disabled people). These withdrawals must be repaid within 10 years.

6. The 1996 and 1997 budgets raised the annual contribution limits on RESPs from $\$ 1,500$ to $\$ 4,000$ per student, and also increased the lifetime limit on contributions from $\$ 31,500$ to $\$ 42,000$. The 1998 budget introduced Canada Education Saving Grants (CESGs) equal to $20 \%$ of RESP contributions up to a limit of a $\$ 400$ annual grant per student. CESG amounts become part of the RESP. The 1998 budget also made it possible to transfer an RESP balance to an RRSP if the student did not go on to qualifying study after leaving high school.

All of these provisions act to increase the net-of-tax expected return to planned or actual human capital investment for some taxpayers. ${ }^{17}$ Note, however, that the incidence of the increased returns varies greatly. Increased education amounts raise $r_{n}$ for almost all students. On the other hand, interest credits only benefit those with student loans, and the RESP/RRSP provisions have similarly limited incidence. Note also that the value of the RESP/RRSP measures will vary substantially even among those who make use of these savings plans. CESG's are proportional to RESP contributions; the benefit of RESP saving depends on how attractive is the after-tax rate of return on the next-best saving vehicle; the value of the option to rollover unused RESP funds into an RRSP depends on how likely it is that education plans will fall through; and the benefit of being able to take money out of an RRSP temporarily to finance education depends on the size of the tax rate thereby avoided.

Since 1998 the most important PIT changes affecting human capital have been (i) a doubling of the education amounts in the 2001 tax year (to $\$ 400$ and $\$ 120$ per month for full-time and part-time students respectively), (ii) reductions in federal tax rates and changes in the rate structure, and (iii) the freeing-up of provincial PIT rate structures. ${ }^{18}$ By the 2001 tax year the federal government had moved from its sharply graduated three bracket rate structure to more gradual progressivity. Federal rates were applied at the rates of $16,22,26$, and $29 \%$ on taxable income in the ranges 0 - $\$ 30,754, \$ 30,755$ $\$ 61,509, \$ 61,510-\$ 100,000$, and $\$ 100,000+$. All federal surtaxes had been removed. Including provincial taxes, full marginal rates in the four brackets were $24 \%, 33 \%, 40 \%$, and $44 \%$. The reduced progressivity should reduce human capital ETR's somewhat.

Prior to the 2001 tax year all nine provinces that were signatories to the federalprovincial tax collection agreements were bound to levy their basic PIT as a flat $\%$ of the basic federal tax. Quebec levied and collected its own separate PIT. Under this arrangement, federal surtaxes did not affect provincial PIT, and the provinces were free to enact their own surtaxes and credits additional to those provided by Ottawa. While in the 1970s and 80s provincial PIT payments could broadly be thought of as proportional to 
federal, by 1998 this approximation was becoming strained. Some provinces, notably Ontario, levied surtaxes, and a wide range of provincial credits were provided, e.g. for provincial political contributions, qualifying investments, property and sales taxes, and dependent children. Finally, the Quebec rate structure was somewhat less progressive than the federal structure, featuring marginal rates of $17 \%, 21.25 \%$, and $24.5 \%$ on taxable incomes of 0 - $\$ 26,000, \$ 26,001-\$ 52,000$, and $\$ 52,000+$ in 2001 , for example.

Beginning in 2001 provinces covered by the tax collection agreements are free to levy tax as a function of federal taxable income rather than basic federal tax. This has already led to significant differences in rate structure across the provinces, and divergence from the federal structure. While six provinces kept the three-bracket structure for 2001, New Brunswick followed the federal lead to create a new $\$ 100,000+$ bracket. Alberta introduced a flat tax at a 10\% rate. British Columbia introduced five brackets, with the top one beginning at $\$ 85,000$.

\section{Payroll Taxes}

In 1998 employees and employers each paid Canada Pension Plan (CPP) contributions at a rate of $3.2 \%$ on earnings, with a cap reached at maximum pensionable earnings of $\$ 36,900$. Employment insurance (EI) contributions were paid at a rate of $2.7 \%$ by the employee and $3.78 \%$ by the employer, on earnings up to $\$ 39,000$. For workers whose earnings did not exceed $\$ 36,900$ the payroll rate structure was mildly progressive, since the first $\$ 3,500$ of earnings were not subject to CPP contributions. However, for middle and high earners, the system was clearly regressive. This regressivity should offset the positive effect of PIT progressivity on human capital ETRS to some extent.

\section{Student Loan Plans}

Both the provinces and the federal government help students to finance their education by providing guaranteed student loans. The provinces are responsible for administration. Attempting to take into account variations in provincial plans is beyond the scope of this study. Here we have modelled the effects of the Canada and Ontario Student Loan Plans (CSLP and OSLP). The results should be reasonably representative for the country as whole since the federal and provincial governments instituted reforms in 1995/96 to achieve a fairly high degree of standardization. (See e.g. Finnie and Schwartz, 1996.)

The CSLP/ OSLP system allows students to take out loans up to a limit which equals allowable education expenses minus the student's expected contribution. The latter is calculated taking family resources and dependants (e.g. children of a single parent) into account. Maximum loan amounts are \$165 per week from the federal government and about $\$ 110$ per week from provincial governments, for a total of $\$ 9,350$ over a 34 week school year. Importantly, interest is paid by the government sponsors of the plan until six months after graduation. Beyond that point the loans must normally be paid back within a period of $9 \frac{1}{2}$ years. Finnie (2001) finds that graduates, on average, pay the loans back quite quickly. Statistics Canada's National Graduate Survey (NGS) 
found that for 1995 first-degree university graduates (the latest cohort for which figures are available) about $40 \%$ of debt had been repaid after two years (Finnie, 2001, Figure 4).

In recent years student loans have become controversial, for two reasons. First, the default rate has been growing, and there have been concerns that defaulters are treated too leniently. Second, there has been some alarm at reports of substantial accumulated debts. A wide range of average amounts of debt have been reported in the media, with differences depending on which students are included, whether the average is taken for just those students in debt or for all students, and so on. According to the Department of Finance (1998), for a typical graduate with student loans, debt loads following a four-year post-secondary program averaged $\$ 13,000$ in 1990-91, and could be expected to rise to $\$ 25,000$ in 1998-99. On the other hand, the NGS results show average debt of only about \$10,000 for 1990 grads with loans and \$13,600 for 1995 grads. The incidence of debt in the NGS was about 46\% for both the 1990 and 1995 graduates. (See Finnie, 2001, Figure 1.)

In order to prevent students defaulting on their loans, prior to 1997 those who could demonstrate financial hardship received up to 18 months of interest relief. In 1997 relief was extended to 30 months. The February 1998 budget extended the maximum period of interest relief to 54 months. In order to qualify for full interest relief gross earnings had to be less than $\$ 22,300$ as of April 1998. ${ }^{19}$ (Prior to this the cutoff had been $\$ 20,460$.) And in order to go from 30 to 54 months' relief individuals had to qualify as still being in financial hardship after their loans had been rescheduled to cover a 15 year period. Finally, for those individuals who still remain in financial difficulties, the government will reduce the loan principal if annual payments exceed, on average, $15 \%$ of income. Maximum assistance is limited to the lesser of $\$ 10,000$ or $50 \%$ of the loan. To qualify, five years must have passed since the completion of study and normal interest relief must have been exhausted. ${ }^{20}$

Together with the tax provisions discussed earlier, the CSLP changes in the 1998 budget substantially increased support for post-secondary students. The modified CSLP can be viewed as a crude income contingent student loan plan. The expectation is that the majority of students will pay off their loans in full, but very sizeable reductions in the effective burden of student loans will be provided to a significant group with low incomes.

\section{Effective Tax Rates on Undergraduate University Education in Canada}

\section{Data and Assumptions}

In order to gauge the typical size of ETR's in Canada we compute representative values of the net- and gross-of-tax rates of return, $r_{n}$ and $r_{g}$. To do this we use Statistics Canada's 1995 Survey of Consumer Finance (SCF) to model actual and potential earnings, $E_{t}$ and $E_{t}^{*}$, before- and after-tax. We perform our calculations as if the 1995 cross-section was a snapshot from an economy in steady state. ${ }^{21}$ From this dataset we 
took median earnings (and other quantiles) of full-time male and female workers conditioned on the highest completed level of schooling being high school or a bachelor's degree, as the basis for $E_{t}^{*}$ and $E_{t}$ respectively. ${ }^{22}$ We have used median rather than mean earnings since we wish to investigate rates of return and ETRs for an "average" student. Since earnings are positively skewed the mean is above the median and is not representative for the typical student.

The estimation of $E_{t}, E_{t}^{*}$, and their differential is clearly critical. This requires specification of a counterfactual scenario. How much would the university graduate have earned if he/she had stopped formal education after high school? Our counterfactual says they would have received the median amount earned by high school graduates of the same age and gender. Some authors have argued that university graduates have greater ability and that an ability differential (typically 10 or $15 \%$ ) therefore needs to be applied to the earnings of high school graduates when forming the counterfactual. (See e.g. Stager, 1994) We take a comparative advantage view, in which it is not necessarily clear that the median university graduate would have earned more than the median high school grad if his/her education had been terminated after high school. ${ }^{23}$

An alternative to our approach would be to estimate human capital earnings equations, and to form the counterfactual by reducing the value of the years of schooling variable for university graduates. This approach would allow more variables that affect earnings to be held constant than are controlled in our approach. We hold constant age, gender, and hours of work. The additional variables that could be controlled for in a regression approach could include e.g. occupation, industry, region, union membership, marital status, and fertility. While the results of such an exercise would be of interest, we believe there is reason to prefer our approach. Holding these additional variables constant would be inappropriately restrictive. High school and university graduates differ in occupation, industry, region, and so on, in part because of their different levels of education. The reason for obtaining a university degree is often to enter an occupation that would otherwise be inaccessible, and reaping the advantage of one's degree often means moving to a different industry or region. Thus, we do not see being able to hold constant a set of additional characteristics in comparing high school vs. university graduate earnings as an advantage. We are interested in the total, rather than the partial impact of education.

We have specified costs and tax features, as far as possible to be those prevailing in the academic year 1997-98. ${ }^{24}$ In 1997-98 undergraduate Arts tuition (representative for core university programs and likely for median graduates) averaged $\$ 3,253$, and additional fees $\$ 342$, according to Statistics Canada. Other direct expenses (books, supplies, and return transportation to the educational institution) were assumed to be $\$ 1,000$ per year. Thus we estimate total direct expenses to have averaged $\$ 4,595$.

In addition to distinguishing between men and women, the calculations we report below consider part-time and full-time students separately. Full-time students are assumed to work the equivalent of four months per year, during which they would earn the same amount as a high school graduate. As in previous studies we reduce these 
earnings somewhat (by 20\%) to allow for unemployment and job search. ${ }^{25}$ Part-time students are assumed to earn their degrees in six years, as opposed to four for full-time students. We assume that they work year-round - - part-time during the winter months and full-time during the summer. They are assumed to earn half as much as if they were employed full-time year round.

In modelling the taxes paid by workers after graduation we have assumed that they do not claim a credit for a dependant spouse, and in the main results ignore the tax consequences of children. The incidence of dependant spouses has been declining rapidly in recent years, and we expect will be very low over the lifetimes of recent graduates. Ignoring the tax consequences of children leads to an overstatement of tax burdens over the working lifetime, but only a small error in the calculation of the taxes paid on the incremental earnings due to education, as we argued in the last section. We do take the tax treatment of children into account when considering the situation of single parents.

We make no allowance in our main results for deductions from income after graduation. (Personal credits and credits for interest on student loans where appropriate are taken into account.) The principal deduction that could potentially be modelled is that for RRSP/RPP contributions. However, this would be misleading since our calculations only consider earnings over the working lifetime. If we took the tax relief on RRSP/RPP contributions into account we would have to also model the tax paid on withdrawals. Ignoring both contributions and withdrawals should be approximately offsetting. Deductions for RESP contributions are taken into account when we model the impact of CESGs.

\section{Results}

Results from our base case are shown in Table 1. This case uses the 1998 tax system (i.e. as modified by the 1998 federal budget) and assumes a single student with no dependants who finances his/her education without the help of a student loan or an RESP. The estimated rates of return are lower than those found by Vaillancourt (1997) and Stager (1994) using 1991 Census data. Whereas we find the net-of-tax private rate of return was $7.9 \%$ for male full-time university students, and $12.6 \%$ for female, Vaillancourt found figures of 12.3 and $16.1 \%$. Stager obtained private rates of return of $13.8 \%$ for men and $17.6 \%$ for women. Aside from using more recent earnings data, and incorporating the effects of higher tuition fees, our study differs from the two earlier studies by using median rather than mean earnings, and by assuming retirement after age 60 rather than 64 (in order to reflect the move to earlier retirement). These differences act to produce lower estimated rates of return. ${ }^{26}$ 
Table 1

\section{Rates of Return and Effective Tax Rates for First University Degree Graduates: 1998 Tax System, No Student Loans, No Dependants (Base Case)}

\begin{tabular}{|c|c|c|c|}
\hline & $\begin{array}{c}\text { IRR (\%) } \\
\text { Net-of-Tax (1) } \\
\end{array}$ & $\begin{array}{c}\text { IRR (\%) } \\
\text { Gross-of-Tax (2) } \\
\end{array}$ & $\begin{array}{c}\text { ETR } \\
{[(2)-(1)] /(2)}\end{array}$ \\
\hline \multicolumn{4}{|l|}{ Males } \\
\hline Full-Time & 7.94 & 9.84 & 0.193 \\
\hline Part-Time & 7.06 & 9.00 & 0.215 \\
\hline \multicolumn{4}{|l|}{ Females } \\
\hline Full-Time & 12.63 & 14.34 & 0.119 \\
\hline Part-Time & 11.52 & 13.29 & 0.133 \\
\hline
\end{tabular}

Notes: $\quad$ IRR $=$ internal rate of return

$\mathrm{ETR}=$ effective tax rate

Source: Authors' calculations using 1995 Statistics Canada Survey of Consumer Finance data.

A notable feature of these results is that, as in previous studies, the rate of return is considerably higher for females than for males. The reason is that the earnings of women with a university degree are much closer to those of their male counterparts than is the case for workers with only high school. We also find somewhat lower rates of return to part-time than to full-time study. This difference is due mainly to the delay by two years of the earnings benefits of study for the part-timers (since they remain in school that much longer).

Table 1 shows a relatively small difference between gross and net private rates of return for university graduates. The proportional difference is, of course, the effective tax rate. At $19.3 \%$ and $11.9 \%$ for full-time male and female students respectively, the ETRs indicate that, in the no-loan no-RESP case, human capital investment is not taxed as heavily as physical capital. (Recall our earlier discussion of the McKenzie et al., 1998, results.) The difference in ETRs for men and women reflects the impact of progressivity. Male university graduates still earn more than women, and on their earnings increments due to education are therefore taxed more heavily on average. ETRs for those who attend part-time are lower because they spend more time working while going to school, leading to a higher marginal tax rate (i.e. a higher implicit subsidy) on their forgone earnings.

Turning to Table 2 we see the effects not only of taxes, but also of subsidies to universities. The second column shows, again, the gross-of-tax private rate of return, which does not take subsidies into account. The first column figures in the direct costs of university education which are funded by government and which do not enter the private calculation. ${ }^{27}$ An effective subsidy rate $(E S R)$ can be calculated as the proportional difference between these rates of return. We find that the subsidy rates obtained are 
greater than the effective tax rates shown in Table 1 for all cases. ${ }^{28}$ We thus find a negative net effective tax rate, ETR - ESR, as shown in the last column of the table. This would imply that overall the public sector encourages human capital investment - - a conclusion that is in line with the results of earlier studies and that will be strengthened by taking into account student loans and other forms of special assistance to postsecondary students analyzed below.

Table 2

Base Case Rates of Return, Effective Subsidy Rates, and Tax Minus Subsidy Rate

\begin{tabular}{|c|c|c|c|c|}
\cline { 2 - 5 } \multicolumn{1}{c|}{} & $\begin{array}{c}\text { IRR (\%) } \\
\text { Public (1) }\end{array}$ & $\begin{array}{c}\text { IRR (\%) } \\
\text { Gross-of-Tax } \\
\text { Private (2) }\end{array}$ & $\begin{array}{c}\text { ESR } \\
\text { [(2) - (1)]/(2) }\end{array}$ & ETR - ESR \\
\hline Males & & & & \\
$\quad$ Full-Time & 7.37 & 9.84 & 0.251 & -0.058 \\
$\quad$ Part-Time & 6.86 & 9.00 & 0.238 & -0.023 \\
Females & & & & -0.157 \\
$\quad$ Full-Time & 10.39 & 14.34 & 0.276 & -0.126 \\
Part-Time & 9.85 & 13.29 & 0.259 & \\
\hline
\end{tabular}

Notes: Definition of base case is as in Table 1.

$\mathrm{ESR}=$ effective subsidy rate

ETR, IRR - see Table 1.

Source: See Table 1.

Next we take into account the impacts of student loan financing on private rates of return and ETR's. As Table 3 shows, both gross and net private rates of return increase with the student loan amount. The reason for this increase lies mainly in the fact that interest is not paid until graduation, providing a subsidy that of course increases with the size of the loan. ${ }^{29}$ The net rate of return is more strongly affected because the implicit subsidy is larger relative to after-tax than before-tax earnings. The result is that, even without interest deductibility, providing student loans would reduce the effective tax rate significantly. This aspect is reinforced by the provision of interest deductibility on student loans. Both effects are present in Table 3. For males the tax rate declines from $19.3 \%$ in the no loan case to just $17.2 \%$ with $\$ 15,000$ in loans. For females, the drop is even larger: from $11.9 \%$ to $8.3 \%$. 
Table 3

\section{Rates of Return and Effective Tax Rates for Full-Time Students, 1998 Tax System With Student Loans}

\begin{tabular}{|c|c|c|c|c|c|c|}
\hline $\begin{array}{c}\text { Sex and } \\
\text { Dependants }\end{array}$ & $\begin{array}{l}\text { Value of } \\
\text { Loan (\$) }\end{array}$ & $\begin{array}{c}\text { IRR (\%) } \\
\text { Net-of-Tax (1) }\end{array}$ & $\begin{array}{c}\text { IRR (\%) } \\
\text { Gross-of-Tax (2) }\end{array}$ & $\begin{array}{c}\text { ETR } \\
{[(2)-(1)] /(2)}\end{array}$ & $\mathrm{ESR}^{*}$ & ETR - ESR \\
\hline $\begin{array}{l}\text { Male, } \\
\text { No Dependants }\end{array}$ & $\begin{array}{c}0 \text { (base case) } \\
5000 \\
10000 \\
15000 \\
30000\end{array}$ & $\begin{array}{r}7.94 \\
8.15 \\
8.39 \\
8.66 \\
10.31\end{array}$ & $\begin{array}{r}9.84 \\
10.03 \\
10.24 \\
10.46 \\
11.77\end{array}$ & $\begin{array}{l}0.193 \\
0.187 \\
0.180 \\
0.172 \\
0.124\end{array}$ & $\begin{array}{l}0.251 \\
0.265 \\
0.280 \\
0.296 \\
0.374\end{array}$ & $\begin{array}{l}-0.058 \\
-0.078 \\
-0.100 \\
-0.124 \\
-0.250\end{array}$ \\
\hline $\begin{array}{l}\text { Female, } \\
\text { No Dependants }\end{array}$ & $\begin{array}{r}0 \\
5000 \\
10000 \\
15000 \\
30000\end{array}$ & $\begin{array}{l}12.63 \\
13.20 \\
13.88 \\
14.70 \\
20.49\end{array}$ & $\begin{array}{l}14.34 \\
14.83 \\
15.38 \\
16.03 \\
19.81\end{array}$ & $\begin{array}{r}0.119 \\
0.110 \\
0.098 \\
0.083 \\
-0.034\end{array}$ & $\begin{array}{l}0.276 \\
0.299 \\
0.324 \\
0.352 \\
0.475\end{array}$ & $\begin{array}{l}-0.157 \\
-0.189 \\
-0.226 \\
-0.269 \\
-0.509\end{array}$ \\
\hline
\end{tabular}

Notes: 1) The zero loan case without dependants is the same as the base case considered in Tables 1 and 2.

2) The female single parent is assumed to have had a child at age 18. This child will generate a child care expense deduction until the parent is aged 25. Canada Study Grants, which were offered starting in 1999, are not included.

3 ) For the $\$ 30,000$ loan, $\$ 2,000$ of the principal qualifies for loan forgiveness. See Appendix B.

$4){ }^{*} E S R=[(2)-($ appropriate entry from col. 1 of Table 2) $] /(2)$

Source: See Table 1. 
Table 3 illustrates another interesting point. As we increase the loan amount up to $\$ 15,000$ there is a roughly linear decrease in the ETR. But, when the loan is raised to $\$ 30,000$ there is a larger decline in the ETR. In the female case, for example, the ETR becomes negative, falling to $-3.4 \%$. The reason is that in Ontario a student with a $\$ 30,000$ loan would qualify for loan forgiveness on $\$ 2,000$ of the principal. Once again, the effect on the estimated rates of return is higher for the net- than for the gross-of-tax return. In fact, the difference in these impacts is so large that we obtain a negative effective ETR.

The single female parent case reported in Table 3 shows that family status may significantly affect tax impacts on education in Canada. The gross rates of return for a single female parent are taken to be the same as those for a woman without children, but the net rates of return are lower since after-tax forgone earnings are enlarged by the child care expense deduction. The result is that the ETR is higher for a single parent. Also note that the ETR falls less rapidly as the student loan amount is increased than in the case without dependants. This is because before- and after-tax forgone earnings are more similar for the single parent, so that loan benefits do not differ greatly in relative importance between gross vs. net of tax calculations.

The second last column of Table 3 shows the impact of student loans on the expenditure side. The ESR rises quite strongly with the loan amount, increasing from $25.1 \%$ without loans to $29.6 \%$ with a $\$ 15,000$ loan for males, and from $27.6 \%$ to $35.2 \%$ for females. Putting the impacts on the ETRs and ESRs together, a $\$ 15,000$ student loan decreases the net effective tax rate, ETR $-E S R$, from $-5.8 \%$ to $-12.3 \%$ for males and from $-15.6 \%$ to $-26.9 \%$ for females. At a rough guess, these numbers suggest that the median ETR - ESR for all students may have been about $-9 \%$ for males and $-21 \%$ for females in $1998 .{ }^{30}$ For males and females together median ETR - ESR may then have been around $-15 \%$. This represents fairly significant encouragement of human capital investment, especially when we bear in mind our earlier conclusion that the average EMTR for physical capital in Canada likely totalled at least $30 \%$.

Table 4 shows part-time results corresponding to the full-time case shown in Table 3. In the part-time case we find that the size of loan has little impact on the ETR. This is because part-timers pay interest on their student loans from the time they are taken out, rather than benefiting from zero interest payments until six months after graduation like full-time students. 


\section{Table 4}

\section{Rates of Return and Effective Tax Rates for Part-Time Students, 1998 Tax System With Student Loans}

\begin{tabular}{|c|c|c|c|c|c|c|}
\hline $\begin{array}{c}\text { Sex and } \\
\text { Dependants }\end{array}$ & $\begin{array}{l}\text { Value of } \\
\text { Loan (\$) }\end{array}$ & $\begin{array}{c}\text { IRR (\%) } \\
\text { Net-of-Tax (1) } \\
\end{array}$ & $\begin{array}{c}\text { IRR (\%) } \\
\text { Gross-of-Tax (2) } \\
\end{array}$ & $\begin{array}{c}\text { ETR } \\
{[(2)-(1)] /(2)}\end{array}$ & $\mathrm{ESR}^{*}$ & ETR - ESR \\
\hline $\begin{array}{l}\text { Male, } \\
\text { No Dependants }\end{array}$ & $\begin{array}{r}0 \\
5000 \\
10000 \\
15000\end{array}$ & $\begin{array}{l}7.06 \\
7.02 \\
6.97 \\
6.92\end{array}$ & $\begin{array}{l}9.00 \\
8.98 \\
8.95 \\
8.92\end{array}$ & $\begin{array}{l}0.215 \\
0.218 \\
0.221 \\
0.224\end{array}$ & $\begin{array}{l}0.238 \\
0.236 \\
0.233 \\
0.231\end{array}$ & $\begin{array}{l}-0.023 \\
-0.018 \\
-0.012 \\
-0.007\end{array}$ \\
\hline $\begin{array}{l}\text { Female, } \\
\text { No Dependants }\end{array}$ & $\begin{array}{r}0 \\
5000 \\
10000 \\
15000\end{array}$ & $\begin{array}{l}11.52 \\
11.58 \\
11.63 \\
11.70\end{array}$ & $\begin{array}{l}13.29 \\
13.35 \\
13.42 \\
13.49\end{array}$ & $\begin{array}{l}0.133 \\
0.133 \\
0.133 \\
0.133\end{array}$ & $\begin{array}{l}0.259 \\
0.262 \\
0.266 \\
0.270\end{array}$ & $\begin{array}{l}-0.126 \\
-0.129 \\
-0.133 \\
-0.137\end{array}$ \\
\hline $\begin{array}{l}\text { Female, } \\
\text { Single Parent } \\
\text { With one child }\end{array}$ & $\begin{array}{r}0 \\
5000 \\
10000 \\
15000\end{array}$ & $\begin{array}{l}11.17 \\
11.21 \\
11.25 \\
11.30\end{array}$ & $\begin{array}{l}13.29 \\
13.35 \\
13.42 \\
13.49\end{array}$ & $\begin{array}{l}0.159 \\
0.160 \\
0.161 \\
0.162\end{array}$ & $\begin{array}{l}0.259 \\
0.262 \\
0.266 \\
0.270\end{array}$ & $\begin{array}{l}-0.100 \\
-0.102 \\
-0.105 \\
-0.108\end{array}$ \\
\hline
\end{tabular}

Notes: 1) The zero loan case without dependants is the same as the base case considered in Tables 1 and 2.

2) The female single parent is assumed to have had a child at age 18. This child will generate a child care expense deduction until the parent is aged 25 . The amount claimed during study is subject to the restrictions imposed in the 1998 federal budget. (See Appendix B.) Canada Study Grants, which will be offered starting in 1999, are not included.

$3){ }^{*} \mathrm{ESR}=[(2)-$ Appropriate entry from col. 1 of Table 2]/(2)

Source: See Table 1. 
Table 5 shows results for full-time university students with interest relief. In order for individuals in our calculations to qualify for 18 or 30 months of interest relief it is sufficient that their earnings should be $2 / 3$ of median after graduation. Rates of return are accordingly lower for this group than for the median achievers studied in Tables $6.1-$ 6.3. We see that providing interest relief has relatively little impact on the calculated effective tax rates. A similar outcome is found for part-time students (see Collins and Davies, 2002).

Table 5 Rates of Return and Effective Tax Rates for Full-Time Students, 1998 Tax System
With $\$ 10,000$ Student Loan and Interest Relief

\begin{tabular}{|c|c|c|c|c|}
\hline $\begin{array}{c}\text { Sex and } \\
\text { Dependants }\end{array}$ & $\begin{array}{l}\text { Interest Relief } \\
\text { (months) }\end{array}$ & $\begin{array}{c}\text { IRR (\%) } \\
\text { Net-of-Tax (1) }\end{array}$ & $\begin{array}{c}\text { IRR (\%) } \\
\text { Gross-of-Tax (2) }\end{array}$ & $\begin{array}{c}\text { ETR } \\
{[(2)-(1)] /(2)}\end{array}$ \\
\hline \multirow[t]{3}{*}{$\begin{array}{l}\text { Male, } \\
\text { No Dependants }\end{array}$} & 0 & 6.54 & 7.45 & 0.122 \\
\hline & 18 & 6.66 & 7.55 & 0.118 \\
\hline & 30 & 6.72 & 7.60 & 0.116 \\
\hline \multirow{4}{*}{$\begin{array}{l}\text { Female, } \\
\text { No Dependants }\end{array}$} & & & & \\
\hline & 0 & 10.86 & 11.37 & 0.045 \\
\hline & 18 & 11.04 & 11.51 & 0.041 \\
\hline & 30 & 11.14 & 11.59 & 0.039 \\
\hline \multicolumn{5}{|l|}{ Female, } \\
\hline Single Parent & 0 & 10.06 & 11.37 & 0.115 \\
\hline \multirow[t]{2}{*}{ With one child } & 18 & 10.18 & 11.51 & 0.116 \\
\hline & 30 & 10.24 & 11.59 & 0.116 \\
\hline
\end{tabular}

Notes: 1) Assumptions on the female single parent are as in Table 3.

2) Earnings equal $2 / 3$ of median.

Source: See Table 1. 
Next we study the effects of Canada Education Savings Grants (CESG's). ${ }^{31}$ As of Jan. 1, 1998, Canada Education Saving Grants (CESGs) add 20\% to RESP contributions annually, up to a grant limit of $\$ 400$ per child. Net-of-tax rates of return rise and effective tax rates decline. In the case of full-time male university students, for example, Table 6 indicates that the ETR drops from 19.3\% to 15.9\% when parents make $\$ 650$ annual contributions over a 15 year period. If maximum contributions $(\$ 2,000)$ are made, the ETRs fall much further - - to just $7.9 \%$ for full-time males and $-2.3 \%$ for full-time females. Effects for part-time students are also large. These results show that CESGs may have a very powerful effect as they accrue over the coming years.

\section{Table 6}

\section{Rates of Return and Effective Tax Rates with CESGs, 1998 Tax System, No Student Loans, No Dependants}

\begin{tabular}{|l|c|c|c|c|c|c|}
\hline \multicolumn{1}{|c|}{ Sex } & $\begin{array}{c}\text { Yearly } \\
\text { Contribution (\$) }\end{array}$ & $\begin{array}{c}\text { IRR (\%) } \\
\text { Net-of-Tax (1) }\end{array}$ & $\begin{array}{c}\text { IRR (\%) } \\
\text { Gross-of-Tax (2) }\end{array}$ & $\begin{array}{c}\text { ETR } \\
\text { [(2) - (1)] / (2) }\end{array}$ & ESR $^{*}$ & ETR - ESR \\
\hline Male & & & & & & \\
Full-Time & 650 & 8.27 & 9.84 & 0.159 & 0.251 & -0.092 \\
Part-Time & 650 & 7.34 & 9.00 & 0.184 & 0.238 & -0.054 \\
& & & & & & \\
Female & 650 & 13.22 & 14.34 & 0.078 & 0.276 & -0.198 \\
Full-Time & 650 & 12.01 & 13.29 & 0.096 & 0.259 & -0.163 \\
Part-Time & & & & & \\
Male & 2000 & 9.06 & 9.84 & 0.079 & 0.251 & -0.172 \\
Full-Time & 2000 & 7.98 & 9.00 & 0.114 & 0.238 & -0.124 \\
Part-Time & & & & & & \\
Female & 2000 & 14.67 & 14.34 & -0.023 & 0.276 & -0.299 \\
Full-Time & 2000 & 13.18 & 13.29 & 0.008 & 0.259 & -0.251 \\
Part-Time & & & & & \\
\hline
\end{tabular}

Notes: 1) $C E S G=$ Canada Educational Study Grant. CESG benefits incorporated here are based on an example provided by Department of Finance (1998, p. 35). Contributions are made over a 15 year period and earn a $5 \%$ rate of return.

$2){ }^{*} \mathrm{ESR}=[(2)-$ Appropriate entry from col. 1 of Table 2$] /(2)$

Source: See Table 1.

Table 7 replicates the Table 1 case (no student loans and no RESP's), assuming alternatively that the graduate earns at the $25^{\text {th }}$ or the $75^{\text {th }}$ percentile of the earnings distribution, rather than at the median. ${ }^{32}$ We see that for males there is a drop in rates of return and the ETR of going to the $25^{\text {th }}$ percentile case from the median; and there is an increase in going to the $75^{\text {th }}$ percentile. The net-of-tax rate of return varies from $5.4 \%$ for 
the $25^{\text {th }}$ percentile earner to $9.9 \%$ at the $75^{\text {th }}$ percentile, compared with $7.9 \%$ for the median male in Table 1. The ETR ranges from $10.9 \%$ to $24.1 \%$, compared to $19.3 \%$ for the median.

Table 7

Rates of Return and Effective Tax Rates for $25^{\text {th }}$ and $75^{\text {th }}$ Quantiles: 1998 Tax System, No Student Loans, No Dependants

\begin{tabular}{|l|c|c|c|c|}
\hline \multicolumn{1}{|c|}{ Sex } & Quantile & $\begin{array}{c}\text { IRR (\%) } \\
\text { Net-of-Tax (1) }\end{array}$ & $\begin{array}{c}\text { IRR (\%) } \\
\text { Gross-of-Tax (2) }\end{array}$ & $\begin{array}{c}\text { ETR } \\
\text { [(2) - (1)] / (2) }\end{array}$ \\
\hline Male & & & & \\
Full-Time & 25th & 5.35 & 6.00 & 0.109 \\
Part-Time & 25th & 4.29 & 4.92 & 0.129 \\
Female & & & & \\
Full-Time & 25th & 8.46 & 9.09 & 0.070 \\
Part-Time & 25th & 8.69 & 9.49 & 0.081 \\
Male & & & & \\
Full-Time & 75th & 9.88 & 13.02 & 0.241 \\
Part-Time & 75th & 9.16 & 12.19 & 0.248 \\
Female & & & & \\
Full-Time & 75th & 12.42 & 15.25 & 0.186 \\
Part-Time & 75th & 12.95 & 16.22 & 0.202 \\
\hline
\end{tabular}

Source: See Table 1.

For women, rates of return are also lower at the $25^{\text {th }}$ percentile than at the median. The net-of-tax rate of return for full-time students is $8.5 \%$, for example, vs. $12.6 \%$ at the median. The ETR is also lower, at 7.0\% vs. $11.9 \%$ in the base case. However, when we move to the $75^{\text {th }}$ percentile the rates of return rise less, proportionally, than for males, reflecting a less skewed distribution of earnings (and therefore lower peak tax rates on earning gains) among female graduates. The ETR rises only to $18.6 \%$ at the $75^{\text {th }}$ percentile, compared to $24.1 \%$ for males.

The Table 7 results indicate the impact of the graduated rates in the tax system. Effective tax rates on human capital investment rise with the lifetime earnings of graduates. Another way of putting this is that the net-of-tax rates of return on human capital investment are depressed more for high earners.

In order to get a complete assessment of the incentive effect on human capital formation one must of course deduct the ESR from the ETR. Looking back at Table 2 we see that if the graduates at the $75^{\text {th }}$ percentile had the same ESRS as median workers, the 
ETR - ESR figures for males would be $-1.0 \%$ and $1.0 \%$ for full-time and part-time students respectively. Those for females would be $-9.0 \%$ and $-5.7 \%$ for full-time and part-time. However, the assumption that the ESRs at higher percentiles are the same as at the median may be incorrect. The highest paid graduates are those in professional programs like engineering and medicine, which in 1997-98 were still more heavily subsidized than general arts and science programs. Vaillancourt (1997) finds that the difference is sufficient that the net subsidy rates (i.e. ESR - ETR ) in 1990 were highest in science, engineering and medicine and lowest in the humanities and social science. ${ }^{33}$

Finally, we have generated results (not shown) corresponding to Tables 6.1, 6.3, and 6.4 for the tax system as it existed in 1997, that is prior to the major changes of the February 1998 federal budget. We found that the difference in 1997 vs. 1998 results for full-time students without student loans or RESPs were small. These differences come from the fact that the education amount was just $\$ 150$ per month in 1997 for full-timers compared to $\$ 200$ per month in 1998 . After-tax rates of return were slightly lower, and ETRs slightly higher, in 1997 for part-timers however, since they received no education amount tax credit. A monthly credit of $\$ 60$ was introduced for part-timers in the 1998 budget.

We also found that the effects of the interest credit on student loans introduced in 1998 are quite small. For loans of up to $\$ 10,000$ net-of-tax rates of return are less than $0.1 \%$ points lower under the 1997 system, and the difference in ETR's is correspondingly small. Compared to the impacts of CESGs, the credit for interest on student loans has a relatively weak effect. 


\section{Conclusion}

We have argued that effective tax rates are a useful device for summing up the effects of the tax system on the incentive to invest in human capital, and have illustrated the approach for undergraduate university level education in Canada. Our analysis has concentrated on two broad features of effective tax rates - - how high they are for the median person, and how they vary across individuals.

We have found that there is a notable difference between the effective tax rate on human capital coming from the tax system per se (the ETR) and the net effective tax rate, which subtracts the effective subsidy rate (the ESR) on the expenditure side. For median earners, ETRs on human capital are sizeable, although lower than effective marginal tax rates for physical capital in Canada. This is true even in the wake of the federal budgets of 1996, 1997 and 1998, which introduced a wide range of measures that reduced ETRs. On the other hand, ETR - ESR at the median is about $-9 \%$ for males and $-21 \%$ for females. Thus, government provides more incentive on the expenditure side for investment in university education than disincentive on the tax side.

Whether a net effective tax rate on human capital that averages about $-15 \%$ across the sexes is appropriate is an interesting question. For this to be supported on efficiency grounds it is likely that one would have to appeal to externality arguments. Students' liquidity constraints could also help to justify the negative ETR - ESR, although the potential importance of this factor is significantly eroded by Canada's quite generous system of student loans. In view of the substantial positive effective tax rates on physical capital, there is certainly a possibility that, from an efficiency standpoint, as of the late 1990's Canadian governments provided too much encouragement for university study. Since tuition fees have risen quite significantly in the last four or five years, one must caution, however, that if this was indeed a problem its correction may already have occurred.

We have also found that the taxation of human capital is far from uniform in Canada. This raises the possibility of distortions in the supply of human capital, with too much investment taking place in programs, or by individuals, with low ETRs, and too little occurring where ETRs are high. We have found that ETRs differ depending on income after graduation, full-time vs. part-time study, receipt of student loans, gender, presence of dependants, and use of RESPs. For example, we found that ETRs for fulltime students who go on to earn at the $75^{\text {th }}$ percentile of the earnings distribution throughout their lifetimes are higher than for those earning at the $25^{\text {th }}$ percentile. In view of the strong association between earnings and area of university studies this may have interesting implications for the composition of human capital investment. Other things equal, the highest ETRs will be felt by graduates in areas such as business, engineering, and medicine. At the opposite extreme are graduates in the humanities. We have seen that in some of the high tax areas there has in the past been an offsetting effect in the form of heavy direct subsidies. However, the tendency to allow tuition fees to rise in recent years, especially in more specialized programs, may be eroding that offset. 
It is possible that the provisions of the 1998 federal budget, and the doubling of the education amount tax credit in 2001, may not only have reduced the tax-side disincentive for human capital investment, but may also have reduced non-uniformity in ETRs. Increases in the education amount have a broadly based impact that has lowered ETRs for the majority of students. The special provisions for part-time students and those with dependants reduce ETRs for people whose human capital investments were lessfavored by the tax system. And in the future, as higher income taxpayers take increasing advantage of Canada Education Savings Grants (CESGs) they should see some reduction in their ETRs.

While the analytical framework we have introduced can be applied to human capital investment at any level, our numerical results have been confined to the case of first-degree university graduates. It would be interesting to extend the results in order to compute ETRs on completed high school, community college, incomplete college and university studies, post-graduate work and on-the-job training (OJT). We expect that effective tax rates are lower for high school completion, community college, and incomplete post-secondary studies than for undergraduate university degrees. This result is likely in view of the importance of income level in determining ETRs. Results for post-graduates are harder to anticipate since rates of return to graduate study are much lower than for undergraduate programs, and ETRs could be very sensitive to small absolute differences in gross and net rates of return.

Attention to the ETR on OJT would be valuable since it is clear that a large element of human capital is formed on the job. There is good reason to expect much lower ETRs than for formal schooling. In general firms and workers share the costs of such training. Workers do so by receiving lower wages or salaries during training. But progressivity effects are likely to be much less serious than for formal schooling, since it is only a portion of earnings that is being given up and the tax rate on foregone earnings may not be much less than that on the earnings increments due to training. On the employer's part, at least for corporations the tax rate is constant, so that there is no progressivity effect at all. Hence ETRs for OJT, like effective subsidy rates, may be quite small. 


\section{References}

Acemoglu, Daron J., and Joshua Angrist, "How Large are the Social Returns to Education? Evidence from Compulsory Schooling Laws", NBER Macroeconomics Annual, 15: 9-58.

Boadway, Robin, Neil Bruce and Jack Mintz, "Taxation, Inflation and the Effective Marginal Tax Rate on Capital in Canada", Canadian Journal of Economics 17 (1984), pp. 62-79.

Boskin, M.J., "Notes on the Tax Treatment of Human Capital", in Conference on Tax Research, Office of Tax Analysis, Department of the Treasury, Washington, D.C., 1975.

Bovenberg, A. Lans and Bas Jacobs, "Redistribution and Education Subsidies are Siamese Twins", CentER Discussion Paper 2001-82, Tilburg University, 2001.

Cameron, Stephen, and Christopher Taber, Borrowing Constraints and the Returns to Schooling", NBER Working Paper 7761, 2000.

Canadian Tax Foundation, Finances of the Nation 1998, Toronto, 1999.

Chamley, Christophe, "Optimal Taxation of Capital Income in General Equilibrium With Infinite Lives", Econometrica 54 (3): 607-622, 1986.

Collins, Kirk A., and James B. Davies, "Taxing Investments in Higher Education", University of Western Ontario, mimeo, 2002.

Davies, James B., "Empirical Evidence on Human Capital Externalities", University of Western Ontario, mimeo, 2002.

Davies, James B. and Graham Glenday, "Accrual Equivalent Marginal Tax Rates for Personal Financial Assets", Canadian Journal of Economics 23: 189-209, 1990.

Davies, James B. and John Whalley. "Taxes and Capital Formation: How Important is Human Capital?" in National Saving and Economic Performance edited by D.Bernheim and J.Shoven, Chicago, University of Chicago Press, 1991, pp.169-197.

Davies, James B., Jie Zhang and Jinli Zeng, "Optimal Fiscal Policy in a TwoSector Growth Model With Transitional Dynamics", University of Western Ontario, mimeo, 2002.

Department of Finance, The Canadian Opportunities Strategy, Ottawa, February 1998 budget paper. 
Dupor, Bill, Lance Lochner, Christopher Taber and Mary Beth Wittekind, "Some Effects of Taxes on Schooling and Training", American Economic Review 86 (1996), pp. 340-46.

Finnie, Ross, and Saul Schwartz, Student Loans in Canada, C.D. Howe Institute, Toronto, 1996.

Finnie, Ross, "Measuring the Load, Easing the Burden: Canada's Student Loan Programs and the Revitalization of Canadian Postsecondary Education", C.D. Howe Commentary 155 (November), 2001.

Heckman James J. and Peter J. Klenow, "Human Capital Policy", University of Chicago, 1997, forthcoming in M. Boskin (ed.), Understanding Economic Growth, Hoover Institution Press, Stanford.

Heckman, James J., Lance Lochner and Christopher Taber, "General Equilibrium Cost-Benefit Analysis of Education and Tax Policies", in Gustav Ranis and Lakshmi K. Raut (eds.), Trade, growth and development: Essays in honor of Prof. T.N. Srinivasan, Contributions to Economic Analysis, Vol. 242. Amsterdam; New York and Oxford: Elsevier Science, North-Holland, 1999, pp. 291-349.

Jones, Larry E., Rodolfo E. Manuelli, and Peter E. Rossi, "Optimal Taxation in Models of Endogenous Technological Change", Journal of Political Economy 101 (3): 485-517, 1993.

Jones, Larry E., Rodolfo E. Manuelli, and Peter E. Rossi, "On the Optimal Taxation of Capital Income", Journal of Economic Theory 73: 93-117, 1997.

Judd, Kenneth L., "Redistributive Taxation in a Simple Perfect Foresight Model", Journal of Public Economics 28: 59-83, 1985.

Kaplow, Louis, "On the Divergence Between 'Ideal' and Conventional IncomeTax Treatment of Human Capital", American Economic Review 86, 1996, pp. 347-52.

Kesselman, Jonathan, and Finn Poschmann, "A New Option for Retirement Saving - - Tax-Prepaid Savings Plans", C.D.Howe Institute, Toronto, Commentary No. 149, 2001.

King, M.A., and D. Fullerton. The Taxation of Income From Capital: A Comparative Study of the United States, United Kingdom, Sweden and West Germany, Chicago: University of Chicago Press, 1984. 
McKenzie, Kenneth J., Mario Mansour, and Ariane Brule, "The Calculation of Marginal Effective Tax Rates", Working Paper 97-15, Technical Committee on Business Taxation, Department of Finance, Ottawa, 1998.

Mintz, Jack M., Most Favored Nation: Building a Framework for Smart Economic Policy, C.D. Howe Institute, Toronto, Policy Studies 36, 2001.

Morisette, Rene, "The Declining Labour Market Status of Young Men", in Statistics Canada, Labour Markets, Social Institutions, and the Future of Canada's Children, Publication No. 89-553-XPB, Ottawa, 1998, Chapter 3, pp. 31-50.

Nielsen, Soren B., and Peter B. Sorensen, "On the Optimality of the Nordic System of Dual Income Taxation", Journal of Public Economics, 63: 311-329, 1997.

Pecorino, Paul, "Tax Structure and Growth in a Model with Human Capital", Journal of Public Economics 52: 251-271, 1993.

Perroni, Carlo, "Assessing the Dynamic Efficiency Gains of Tax Reform When Human Capital is Endogenous", International Economic Review 36: 907-925, 1995.

Poddar, Satya and Morley D. English, "Canadian Taxation of Personal Investment Income", Canadian Tax Journal 47 (5), 1999, pp. 1270-1304.

Pryor, Frederic L. and David Schaffer, "Wages and the University Educated: A Paradox Resolved”, Monthly Labor Review 120 (7), 1997, pp. 3-14.

Shea, John, "Does Parents' Money Matter?", Journal of Public Economics 77: 155-184, 2000.

Stager, A.A. David. "Returns to Investment in Ontario University Education, 1960-1990, and Implications for Tuition Fee Policy." Council of Ontario Universities, December 1994.

Vaillancourt, Francois. "The Private and Total Returns to Education in Canada, 1985. ” Canadian Journal of Economics;28(3), August 1995, pages 532-54.

Vaillancourt, Francois. "The Private and Total Returns to Education in Canada, 1990: A Note", Centre de recherche et developpement en economique, Universite de Montreal, September 1997 (mimeo). 


\section{Appendix A}

This appendix provides the general form of the basic problem presented in Section II of the paper. In that section we illustrated the calculation of the ETR for the case where the length of the schooling period, $m$, was just one year, and the length of life, $T$, went to infinity. If we do not make those assumptions analytic solutions for the gross and net-of-tax rates of return $r_{g}$ and $r_{n}$, and thus for the ETR, do not exist. The purpose of this appendix is to take the analysis up to the point where numerical solutions must be sought.

The starting point is equation (2) in Section II, which can be used to compute $r_{g}$ in the case where the tax system takes no account of education and there are no student loans:

$$
\sum_{t=1}^{T} \frac{E_{t}-C_{t}}{\left(1+r_{g}\right)^{t-1}}=\sum_{t=1}^{T} \frac{E_{t}^{*}}{\left(1+r_{g}\right)^{t-1}}
$$

As explained in Section II, this equation can also be used to compute the public rate of return, $r_{p}$, if $C_{t}$ is replaced by the full direct costs of education, $C_{t}^{p}$. And it can be used to compute $r_{n}$ if $E_{t}$ and $E_{t}^{*}$ are replaced by the after-tax earnings $E_{t}^{a}$ and $E_{t}^{a *}$.

To bring in the tax treatment of education and student loans we need to modify (2) to take account of (i) amounts $L_{t}$ borrowed in the form of student loans in the schooling period, (ii) repayment of those loans at the interest rate $i$, with tax relief via a credit for a fraction $d$ of interest payments, and (iii) tax credits for tuition and education expenses, $A_{t}$. Introducing these elements will modify both $r_{g}$ and $r_{n}$, but makes no difference to the public rate of return, $r_{p}$.

As explained in Section III of the paper, the scheduling of student loan repayments is flexible in Canada, but they must normally be repaid within 10 years of graduation. Here we let annual payments during this period of $l$ years equal $i \theta\left(L_{t}, t\right)$, where $\theta\left(L_{t}, t\right)$ gives the amount on which interest must be paid each year. This amount is less than the principal in the first year of loan repayment for all student borrowers in Canada, since loans are interest free for the first 6 months after graduation. Also, as explained in Appendix B, in some cases there is interest relief for low-income graduates, which would also reduce the effective amount on which interest is paid below principal. In the calculations reported in our tables we assume principal is paid off on a straight-line basis, but other assumptions could clearly be made.

Finding the internal rates of return $r_{g}$ and $r_{n}$ requires solving the general form of (2) numerically, which can be done with a variety of computer packages, including standard spreadsheets. Note that the RHS is not altered by taking tax 
relief for education or student loans into account, since it shows the present value of the earnings stream without the education in question. Thus we focus on the LHS of (2), which we denote $P V$ in the before-tax case. Taking student loans, but not tax relief on education, into account we have:

(A.1) $P V=\sum_{t=1}^{m} \frac{E_{t}-C_{t}+L_{t}}{\left(1+r_{g}\right)^{t-1}}+\sum_{t=m+1}^{m+l} \frac{E_{t}-i \theta\left(L_{t}, t\right)-R_{t}}{\left(1+r_{g}\right)^{t-1}}+\sum_{t=m+l+1}^{T} \frac{E_{t}}{\left(1+r_{g}\right)^{t-1}}$.

where $R_{t}$ is the repayment of student loan principal in year $t$.

Turning to after-tax values, we have:

(A.2) $P V^{a}=\sum_{t=1}^{m} \frac{E_{t}^{a}-C_{t}+A_{t}+L_{t}}{\left(1+r_{n}\right)^{t-1}}+\sum_{t=m+1}^{m+l} \frac{E_{t}^{a}-i(1-d) \theta\left(L_{t}, t\right)-R_{t}}{\left(1+r_{n}\right)^{t-1}}$

$$
+\sum_{t=m+l+1}^{T} \frac{E_{t}^{a}}{\left(1+r_{n}\right)^{t-1}}
$$

Again, $r_{n}$ is found numerically, by setting $P V^{a}$ equal to the RHS of (2) where $E_{t}^{*}$ is replaced by the after-tax value $E_{t}^{a^{*}}$.

Appendix B details the tuition and "education amount" credits that compose $A_{t}$ in the Canadian case, as well as the rules on student loans. 


\section{Appendix B}

\section{B.1 Basic Data}

1) Our estimates of tuition and additional expenses are based on Statistics Canada data for 1997-8. See http://www.statcan.ca/Daily/English/970825/d970825.htm\#art2. An average was taken over arts degrees across the country.

2) Data on "other expenses" were taken from a variety of sources- Statistics Canada databases, university web sites, and university calendars. "Other expenses" refers to items that are only required for schooling (e.g. books and supplies for schooling).

3) The earnings data come from Statistics Canada's 1995 Survey of Consumer Finance microdata tape.

\section{B.2 Assumptions on Earnings}

1) Part-time earnings for full-time students are assumed to be summer earnings and therefore comprise a maximum of four months of earnings potential. To account for unemployment and job search the value is reduced by $20 \%$.

2) We assume that part-time students work part-time during the regular school year and full-time in the summer. This motivates the further assumption that their annual earnings are half of full-time earnings. A part-time student is assumed to take, on average, 3.3 courses a year. This assumption allows for a part-time student to get a four-year degree in approximately six years. Taking more than three courses in a normal school year would qualify a person as full-time. Therefore, it is assumed that a part-time individual works, as mentioned, year round and goes to school year round. He/she takes 2.5 courses during the school year and 1 during the summer, accordingly, to finish his/her degree (requiring 20 credits in a 5 credit/year school).

\section{B.3 Public Rates of Return}

1) Data on government spending and enrollment for male and female, full-time and part-time students were obtained from the Statistics Canada website. The most recent data available at this site were expenditure values on education and enrollment figures for 1995-96. It is these figures that are used to calculate the public rate of return.

2) Current and capital expenditures on undergraduate instruction are assumed to to equal one half of operating expenditures. The justification for this assumption is given in the text of the paper. 
3) Public expenditures per student are calculated as in Vaillancourt (1995).

Operating expenditure on universities is divided by full-time equivalent (FTE) enrollment, where a part-time student counts as one third of a full-time student.

4) Public expenditures per part-time student are assumed to be one third of those for full-time students, in line with point 3.

\section{B.4 Tax Features}

\section{B.4.i) Tax Credits}

In addition to basic personal amounts, students are eligible for non-refundable credits on tuition and certain additional fees. They may also be eligible for nonrefundable credits in the form of the education amount, and on interest paid on student loans. As outlined in the paper, the education amount was $\$ 150$ per month in 1997 and \$200 per month in 1998 for full-time students. Part-time students did not receive the education amount in 1997, but could claim $\$ 60$ per month in 1998. The taxpayer earns a net credit applicable to federal tax equal to $17 \%$ of the amount claimed, and there is a further credit against provincial tax. We assume that the sum of the two equals 25\%, as it did in Ontario in 1998.

\section{B.4.ii) Child Care Expense Deduction (CCED)}

1) In 1998, the government allowed taxpayers to deduct from taxable income child care expenses of up to $\$ 7,000$ for each eligible child under seven years of age. A deduction of up to $\$ 4,000$ was allowed for children aged 7 to 16 .

2) For full-time students we assume that child care expenses equal $\$ 4200$ ( $\$ 350 *$ 12 months), and that these expenses only last until the child is seven years old. We assume that the child is one year old when the parent is 19 . Therefore, child care expenses are only deducted up until the age of 25 .

3) Most part-time students were not eligible to claim CCED prior to the 1998 budget. The latter allowed part-time students to deduct up to $\$ 2200$. We assume that a part-time student with a dependant would be at this maximum.

\section{B.4.iii) Registered Education Savings Plans (RESPs) and Canada Education Savings Grants (CESG's)}

1) In both 1997 and 1998 the federal government allowed taxpayers to contribute up to $\$ 4,000$ per child to an RESP. 
2) Since January 1, 1998 the federal government has been providing a CESG, equal to $20 \%$ of the first $\$ 2,000$ of RESP contributions per child. We assume alternative RESP contribution values of \$650/year and \$2000+/year in calculating the amount of CESG awarded.

3) The calculation for the CESG amount is based on an example in the 1998 Budget documents, which assumed a 5\% rate of return and a contribution rate of $\$ 650 /$ year. For a contribution rate of $\$ 2000 /$ year the CESG amount increases proportionally.

\section{B.5 Canada Student Loan Plan}

\section{B.5.i) Basic CSLP Repayment Features}

1) Students have a choice upon consolidating their Canada Student Loans. They can either choose a maximum fixed interest rate equal to the bank's prevailing unsecured consumer loan rate, which cannot exceed prime plus $5 \%$, or a maximum floating interest rate of prime plus $2.5 \%$. For Ontario Student Assistance Program (OSAP) loans students pay an interest rate of prime plus $1 \%$.

2) Data on interest rates were taken from the Globe and Mail web site (http://www.globeandmail.ca) on Tuesday, June $30^{\text {th }}, 1998$. The Canadian prime interest rate on this date was equal to $6.50 \%$. Being dependent upon the loan held, the interest rate that a student actually faces may vary significantly. For example, using a prime interest rate $6.5 \%$ would result in an interest rate of anywhere between 7.5-11.5\%, which would have a dramatic effect on the type of repayment plan chosen. For the purposes of this study a middle rate of $9 \%$ is used.

3) Information on CSL and OSAP loans was taken from the following web sites: CSL - (http://www.hrdc-drhc.gc.ca/student_loans/), OSAP - (http://osap.gov.on.ca).

4) The regulations on loan forgiveness under OSAP were taken from the above Government of Ontario address. As of 1997-8, loan forgiveness was only available on loans that exceeded $\$ 7,000$ for two terms of study; two terms being defined as 21-40 weeks of schooling (i.e. any amount of loan exceeding $\$ 7000$ for one eight-month school year was forgiven). For our purposes loan forgiveness only figures into the $\$ 30,000$ loan case, as it is assumed that the loan is broken into four equal parts to coincide with the four years of full-time study. Thus, $\$ 7500 /$ year is being borrowed of which $\$ 500$ is forgiven each year. It should also be noted that part of the loan is forgiven only after the loan(s) is (are) consolidated (meaning that a payment schedule has been agreed upon and signed at a bank). For example, upon graduation $\$ 2,000$ of the $\$ 30,000$ loan will be forgiven and interest payments will be calculated therefore on the remaining $\$ 28,000$, not the entire $\$ 30,000$. Part-time students receive no loan forgiveness, as they do not 
qualify for OSAP loans; one must have at least a $60 \%$ course load (i.e. 3 out of a maximum of 5 courses) to be eligible for such loans.

5) Net-of-tax and gross-of-tax private benefits/costs are calculated taking into account that accruing interest is paid for by government during full-time studies. If individuals are studying part-time they do not benefit from having the interest that accrues on their loan paid off by the government. Part-time individuals must pay the interest on their loan from the moment it is acquired.

6) A part-time student is assumed to be working (approx. $20 \mathrm{hrs} /$ week). Therefore, it is assumed that he/she will not accumulate as much debt as someone who is not working. Thus a part-time person only faces loan amounts that range from \$2500$\$ 15000$ in our calculations.

\section{B.5.ii) Interest Relief under CSLP}

1) For individuals to be able to qualify for interest relief a reduction in median earnings is necessary. For the purposes of this study we use two thirds of median earnings to ensure that individuals fit the specified criteria set forth in the 1998 Budget. As of April 1998, full-time students are able to benefit from full interest relief provided their gross earnings are less than $\$ 22,300$ (prior to this change the value was $\$ 20,460)$.

2) As recently as 1996 interest relief was only available for up to 18 months, but this was changed in 1997 with an extension of the period to 30 months. Once again in 1998 this period has been extended; it is now a maximum of 54 months, although the extension only includes those who are in dire straits financially. To qualify for the extended 54-month period an individual must have exhausted the 30 months of interest relief and still be in financial hardship once the repayment period is extended to 15 years. All of this must take place during the first five years upon leaving school.

3) For those in the most difficulty, the federal government introduced debt reduction in 1998. Upon exhausting all relief and having five years pass since the completion of schooling, if an individual is still in financial hardship he/she can have his/her loan principal reduced if annual payments exceed, on average, $15 \%$ of his/her income. 


\section{Notes}

${ }^{1}$ See e.g. Boskin, 1975; Dupor et al., 1996; Kaplow, 1996; and Heckman et al., 1999.
${ }^{2}$ It would of course be interesting to study ETRs on other levels of education, as discussed briefly in the
conclusion. These would include the ETR on incomplete university education. Estimation of these other
ETRs is beyond the scope of the present study.

${ }^{3}$ Note that tax and expenditure systems may have effects on human capital investment apart from those via tax and subsidy rates. For example, if students are liquidity constrained, taxes that are incurred more after graduation - - e.g. income and payroll taxes - - will encourage human capital investment compared with e.g. consumption taxes. Future research may allow us to take these other aspects into account, and also to investigate the quantitative impact of ETRss e.g. on students' propensity to obtain university education.

${ }^{4}$ In the investment context tax burdens may be evaluated on a stock or flow basis. We do our analysis on a stock basis since this facilitates comparisons with the effective tax rate on physical capital. An alternative is to annualize the impacts and express them as a fraction of unit labor costs, that is to put the analysis on a flow basis. Mintz (2001) partially implements this latter approach.

${ }^{5}$ The problems faced when dealing with human capital are quite different than in the study of physical capital. For example, in calculating EMTR's for physical capital one must specify a scenario concerning the determination of market rates of return. It might be assumed, for example, that Canada is a small player in a perfectly competitive world capital market. In order to pay the world interest rate, a corporation would have to earn a gross rate of return on a debt-financed project sufficient to pay both tax and interest at the world rate. By observing market rates and tax parameters one can infer the before-tax rate of return on a marginal investment. The after-tax return is then found by deducting all taxes. As we shall see, the procedure for human capital is quite different.

${ }^{6}$ The situation for on-the-job training is different. (This is one of the reasons that we do not deal with OJT in this paper. It would require a separate study.) One can imagine OJT being provided in quite small units, and the sensitivity of results to the size of the investment becomes less of a problem. This is because the relevant tax on the employer's side, i.e. the corporate tax, is levied at a flat rate, and provided investments are not too large individuals' marginal tax rates will also not be strongly affected by OJT.

${ }^{7}$ An alternative is to define the ETR as the ratio of the present value of net taxes on labour income over the lifetime to the present value of lifetime earnings. (See Mintz, 2001.) While the two approaches will often produce similar results, this is not always the case. We prefer the approach followed here in part because it does not require any assumption to be made about individuals' discount rates.

${ }^{8}$ Note that "neutral" is used here in a special sense. We do not imply, e.g., that a tax system that is neutral with respect to human capital is non-distortionary in its treatment of human vs. physical capital. That depends on the effective tax rate on physical capital, and also on whether there are any relevant non-tax distortions (e.g. capital market imperfections).

${ }^{9}$ How tax relief for education and student loan aspects can be incorporated in the finite lifetime, multi-year schooling case is set out in Appendix A. Analytic results are not available for $r_{g}, r_{n}$, or the ETR in that case. The rates of return must be computed from more general versions of equation (2).

${ }^{10}$ The public rate of return is similar to the social rate of return. (The only difference is that the public rate of return omits external costs or benefits of education.) From a social viewpoint, whether students take out loans or not has no effect on the costs of, or returns to, education.

${ }^{11}$ In a more comprehensive investigation some other taxes would also be taken into account. In the previous section we remarked on the impact of sales taxes. In addition, corporate income taxes have impacts on human capital formed via on-the-job training. See Collins and Davies (2002). 
${ }^{12}$ The NCBS was clawed back at rates ranging from $12.1 \%$ for one-child families to $26.8 \%$ for a family with three or more children. This means that the credit was already clawed back completely for most families at net income of $\$ 25,921$, where the CCTB clawback kicked in at rates from $2.5 \%$ to $5.0 \%$. The latter relatively low rates mean that the CCTB clawback range is very wide. The clawback affects families with incomes up to $\$ 67,000$ - $\$ 75,000$. However, since the CCTB clawback rates are relatively low, their impact on human capital ETRs would be fairly small.

${ }^{13}$ That is, up to a limit of $\$ 5,000$ minus the part of the credit used by the student to reduce his/her tax liability to zero.

${ }^{14}$ The current contribution limit for RRSPs plus Registered Pension Plans is the lesser of $\$ 13,500$ or $18 \%$ of earnings per year. The dollar limit is slated to rise to $\$ 14,500$ in 2004 and to $\$ 15,500$ in 2005 , after which it will be indexed to the average industrial wage. These levels represent a significant retreat, however, from those promised by earlier federal budgets. The 1984 and 1985 budgets promised a limit of $\$ 15,500$ by 1990 , with subsequent indexation.

${ }^{15}$ Since withdrawals are generally taxed at a low rate, RESP's approximate Roth IRA plans in the U.S., which have non-deductible contributions and tax-free withdrawals. Greater use of this type of sheltered saving has been urged for Canada by e.g. Kesselman and Poschmann (2001).

${ }^{16}$ In Canada interest on mortgages and consumer debt is not tax deductible. This makes paying down these forms of debt a popular form of saving for those in the age range of about $25-45$.

${ }^{17}$ The RESP and RRSP provisions might be seen as raising the rate of return to financial assets. However, the benefits in question are only realized as a result of planned or actual human capital investment. They are therefore regarded here as increasing the net expected return on human capital.

${ }^{18}$ A further change that could have a significant effect on human capital ETR's in the long-run was the reindexation of federal brackets, credits and deductions announced in the February 2000 budget. Lack of indexation erodes the progressivity of the tax system over time, as more and more taxpayers' rising nominal incomes push them into the top tax brackets. This may create a tendency for human capital ETR's to fall over time in a non-indexed system.

${ }^{19}$ The budget also introduced partial interest relief on a sliding scale for those whose incomes exceeded the threshold for full relief by a small amount.

${ }^{20}$ The February 1998 budget also announced a billion dollar Millenium Scholarship Fund, which may reduce the need for student loans somewhat. Finally, in view of the provisions to assist repayment, it was ruled that student loans would survive bankruptcy for 10 years after the completion of studies.

${ }^{21}$ While this assumption is not completely innocuous, the Canadian earnings distribution was in fact very stable in the 1990's. There was little per capita earnings growth, and relative dispersion trended upward only mildly. Under these circumstances, students' forecasts of the earnings gains from education at later ages might not have been markedly different from current differentials.

${ }^{22}$ We also examined individuals with "some post-secondary" education. This group includes those obtaining a community college diploma, but also students who attend university for some time without graduating. Due to difficulty in estimating costs and the fact that this group is not representative of community college graduates we do not show results for this group.

${ }^{23}$ Studies have shown that skill-levels among university graduates are not equivalent and that many have ended up taking jobs which were predominantly held by high school graduates previously. (See, e.g. Pryor and Schaffer, 1997) Therefore, to assume a positive ability differential could be somewhat misleading. 
${ }^{24}$ Using 1997-98 for this purpose allows us to capture the large increases in tuition fees, and the major tax changes that occured over the period 1996 - 1998. When we performed this research the most recent SCF data we could obtain on earnings were for 1995 . We do not regard the slight mismatch in dates as a significant problem since male earnings in Canada were changing very slowly in the mid 1990s. Our detailed assumptions, as well as references to data sources, are set out in Appendix B.

${ }^{25}$ Morisette (1998, p. 32) reports that the unemployment rate for all men aged 17 to 24 in 1996 was $14.8 \%$. In addition, 5.3\% had involuntary part-time employment, for a total of $20.1 \%$ who did not have full-time employment.

${ }^{26}$ The use of medians tends to give lower estimated rates of return because the gap between median and mean earnings rises, both absolutely and proportionally, over the lifetime. Thus our estimates of forgone earnings are closer to those of Vaillancourt and Stager than our estimates of the earnings gain accruing over the working lifetime.

${ }^{27}$ In estimating direct costs one must keep in mind that part of universities' costs are incurred for graduate education, research, and other non-instructional purposes. No estimates are available that separate these functions from undergraduate education. Tenure-track university professors are typically expected to devote $40-50 \%$ of their time to teaching, including graduate teaching. We think a reasonable guess is that about $30 \%$ of operating costs are incurred for undergraduate education. Estimates are also not available for capital costs (interest, depreciation etc.) on a national basis, but Stager (1994) estimates that capital costs are about $60 \%$ of operating costs. On this basis we have a figure of $50 \%(\cong 1.6 \times 30 \%)$ of operating costs as an estimate of total direct costs of undergraduate university education.

${ }^{28}$ The significance of the small variations in the subsidy rate across cases in Table 2 should not be exaggerated. We assume the same tuition fees for male and female students, and are simply pro-rating in our treatment of part-time students. There are no doubt differences in programs of study across these different groups that imply further differences in subsidy rates. Capturing these effects is beyond the scope of our study.

${ }^{29}$ We assume a student loan interest rate of $9 \%$, which is at the centre of the range of rates paid in June 1998 (see Appendix). Since this rate is of similar magnitude to our estimated rates of return to a university degree, the benefit of student loans does not come principally via a low interest rate after graduation.

${ }^{30}$ The discussion in the last section indicated that by 1998 it would be reasonable to expect about half of graduates to have had student loans and the average amount to have been about $\$ 15,000$. We take an average of the ETRs for zero vs $\$ 15,000$ debt.

${ }^{31}$ We do not attempt to estimate the impact of RESP's per se on the ETR's since the effects vary greatly across taxpayers depending on their use of RESP's vs. other saving vehicles. Also, prior to the introduction of CESG's. RESP's were not very popular. Thus we believe the most important effect to study is that of CESG's.

${ }^{32}$ Our counterfactual remains that the university graduates would have earned the median amount if they had finished their formal education after high school. It is possible that this exaggerates both rates of return and ETRs somewhat for those at the $75^{\text {th }}$ percentile and has the opposite effect at the $25^{\text {th }}$ percentile. For this reason the results by income level may be less reliable than those at the median.

${ }^{33}$ The net subsidy rates implied by Vaillancourt's 1990 results for males are $17.6 \%$ in medicine, $10.6 \%$ in engineering, $6.0 \%$ in natural science, $2.2 \%$ in social science and $0.6 \%$ in humanities. These figures represent the difference between private and public rates of return in Panel B of Vaillancourt's Table 3, p. 6. 


\title{
CESifo Working Paper Series
}

\author{
(for full list see www.cesifo.de)
}

899 Ronald MacDonald and Cezary Wójcik, Catching Up: The Role of Demand, Supply and Regulated Price Effects on the Real Exchange Rates of Four Accession Countries, March 2003

900 R. Selten, M. Schreckenberg, T. Pitz, T. Chmura, and S. Kube, Experiments and Simulations on Day-to-Day Route Choice-Behaviour, April 2003

901 Stergios Skaperdas, Restraining the Genuine Homo Economicus: Why the Economy Cannot be Divorced from its Governance, April 2003

902 Yin-Wong Cheung, Menzie D. Chinn, and Antonio Garcia Pascual, What Do We Know about Recent Exchange Rate Models? In-Sample Fit and Out-of-Sample Performance Evaluated, April 2003

903 Mika Widgrén, Enlargements and the Principles of Designing EU - Decision-Making Procedures, April 2003

904 Phornchanok Cumperayot, Dusting off the Perception of Risk and Returns in FOREX Markets, April 2003

905 Kai A Konrad, Inverse Campaigning, April 2003

906 Lars P. Feld and Stefan Voigt, Economic Growth and Judicial Independence: Cross Country Evidence Using a New Set of Indicators, April 2003

907 Giuseppe Bertola and Pietro Garibaldi, The Structure and History of Italian Unemployment, April 2003

908 Robert A.J. Dur and Otto H. Swank, Producing and Manipulating Information, April 2003

909 Christian Gollier, Collective Risk-Taking Decisions with Heterogeneous Beliefs, April 2003

910 Alexander F Wagner, Mathias Dufour, and Friedrich Schneider, Satisfaction not Guaranteed - Institutions and Satisfaction with Democracy in Western Europe, April 2003

911 Ngo Van Long, Raymond Riezman, and Antoine Soubeyran, Trade, Wage Gaps, and Specific Human Capital Accumulation, April 2003

912 Andrea Goldstein, Privatization in Italy 1993-2002: Goals, Institutions, Outcomes, and Outstanding Issues, April 2003 
913 Rajshri Jayaraman and Mandar Oak, The Signaling Role of Municipal Currencies in Local Development, April 2003

914 Volker Grossmann, Managerial Job Assignment and Imperfect Competition in Asymmetric Equilibrium, April 2003

915 Christian Gollier and Richard Zeckhauser, Collective Investment Decision Making with Heterogeneous Time Preferences, April 2003

916 Thomas Moutos and William Scarth, Some Macroeconomic Consequences of Basic Income and Employment Subsidies, April 2003

917 Jan C. van Ours, Has the Dutch Miracle Come to an End?, April 2003

918 Bertil Holmlund, The Rise and Fall of Swedish Unemployment, April 2003

919 Bernd Huber and Marco Runkel, Optimal Design of Intergovernmental Grants under Asymmetric Information, April 2003

920 Klaus Wälde, Endogenous Business Cycles and Growth, April 2003

921 Ramon Castillo and Stergios Skaperdas, All in the Family or Public? Law and Appropriative Costs as Determinants of Ownership Structure, April 2003

922 Peter Fredriksson and Bertil Holmlund, Improving Incentives in Unemployment Insurance: A Review of Recent Research, April 2003

923 Bernard M.S. van Praag and Adam S. Booij, Risk Aversion and the Subjective Time Discount Rate: A Joint Approach, April 2003

924 Yin-Wong Cheung, Kon S. Lai, and Michael Bergman, Dissecting the PPP Puzzle: The Unconventional Roles of Nominal Exchange Rate and Price Adjustment, April 2003

925 Ugo Trivellato and Anna Giraldo, Assessing the 'Choosiness' of Job Seekers. An Exploratory Approach and Evidence for Italy, April 2003

926 Rudi Dornbusch and Stanley Fischer, International Financial Crises, April 2003

927 David-Jan Jansen and Jakob de Haan, Statements of ECB Officials and their Effect on the Level and Volatility of the Euro-Dollar Exchange Rate, April 2003

928 Mario Jametti and Thomas von Ungern-Sternberg, Assessing the Efficiency of an Insurance Provider - A Measurement Error Approach, April 2003

929 Paolo M. Panteghini and Guttorm Schjelderup, Competing for Foreign Direct Investments: A Real Options Approach, April 2003

930 Ansgar Belke, Rainer Fehn, and Neil Foster, Does Venture Capital Investment Spur Employment Growth?, April 2003 
931 Assar Lindbeck, Sten Nyberg, and Jörgen W. Weibull, Social Norms and Welfare State Dynamics, April 2003

932 Myrna Wooders and Ben Zissimos, Hotelling Tax Competition, April 2003

933 Torben M. Andersen, From Excess to Shortage - Recent Developments in the Danish Labour Market, April 2003

934 Paolo M. Panteghini and Carlo Scarpa, Irreversible Investments and Regulatory Risk, April 2003

935 Henrik Jacobsen Kleven and Claus Thustrup Kreiner, The Marginal Cost of Public Funds in OECD Countries. Hours of Work Versus Labor Force Participation, April 2003

936 Klaus Adam, George W. Evans, and Seppo Honkapohja, Are Stationary Hyperinflation Paths Learnable?, April 2003

937 Ulrich Hange, Education Policy and Mobility: Some Basic Results, May 2003

938 Sören Blomquist and Vidar Christiansen, Is there a Case for Public Provision of Private Goods if Preferences are Heterogeneous? An Example with Day Care, May 2003

939 Hendrik Jürges, Kerstin Schneider, and Felix Büchel, The Effect of Central Exit Examinations on Student Achievement: Quasi-experimental Evidence from TIMSS Germany, May 2003

940 Samuel Bentolila and Juan F. Jimeno, Spanish Unemployment: The End of the Wild Ride?, May 2003

941 Thorsten Bayindir-Upmann and Anke Gerber, The Kalai-Smorodinsky Solution in Labor-Market Negotiations, May 2003

942 Ronnie Schöb, Workfare and Trade Unions: Labor Market Repercussions of Welfare Reform, May 2003

943 Marko Köthenbürger, Tax Competition in a Fiscal Union with Decentralized Leadership, May 2003

944 Albert Banal-Estañol, Inés Macho-Stadler, and Jo Seldeslachts, Mergers, Investment Decisions and Internal Organisation, May 2003

945 Kaniska Dam and David Pérez-Castrillo, The Principal-Agent Matching Market, May 2003

946 Ronnie Schöb, The Double Dividend Hypothesis of Environmental Taxes: A Survey, May 2003

947 Erkki Koskela and Mikko Puhakka, Stabilizing Competitive Cycles with Distortionary Taxation, May 2003 
948 Steffen Huck and Kai A. Konrad, Strategic Trade Policy and Merger Profitability, May 2003

949 Frederick van der Ploeg, Beyond the Dogma of the Fixed Book Price Agreement, May 2003

950 Thomas Eichner and Rüdiger Pethig, A Microfoundation of Predator-Prey Dynamics, May 2003

951 Burkhard Heer and Bernd Süssmuth, Cold Progression and its Effects on Income Distribution, May 2003

$952 \mathrm{Yu}-\mathrm{Fu}$ Chen and Michael Funke, Labour Demand in Germany: An Assessment of NonWage Labour Costs, May 2003

953 Hans Gersbach and Hans Haller, Competitive Markets, Collective Decisions and Group Formation, May 2003

954 Armin Falk, Urs Fischbacher, and Simon Gächter, Living in Two Neighborhoods Social Interactions in the LAB, May 2003

955 Margarita Katsimi, Training, Job Security and Incentive Wages, May 2003

956 Clemens Fuest, Bernd Huber, and Jack Mintz, Capital Mobility and Tax Competition: A Survey, May 2003

957 Edward Castronova, The Price of 'Man' and 'Woman': A Hedonic Pricing Model of Avatar Attributes in a Synthetic World, June 2003

958 Laura Bottazzi and Marco Da Rin, Financing Entrepreneurial Firms in Europe: Facts, Issues, and Research Agenda, June 2003

959 Bruno S. Frey and Matthias Benz, Being Independent is a Great Thing: Subjective Evaluations of Self-Employment and Hierarchy, June 2003

960 Aaron Tornell and Frank Westermann, Credit Market Imperfections in Middle Income Countries, June 2003

961 Hans-Werner Sinn and Wolfgang Ochel, Social Union, Convergence and Migration, June 2003

962 Michael P. Devereux, Measuring Taxes on Income from Capital, June 2003

963 Jakob de Haan, Jan-Egbert Sturm and Bjørn Volkerink, How to Measure the Tax Burden on Labour at the Macro-Level?, June 2003

964 Harry Grubert, The Tax Burden on Cross-Border Investment: Company Strategies and Country Responses, June 2003

965 Kirk A. Collins and James B. Davies, Measuring Effective Tax Rates on Human Capital: Methodology and an Application to Canada, June 2003 